\title{
Radiocarbon
}

1993

\section{HIGH-PRECISION BIDECADAL CALIBRATION OF THE RADIOCARBON TIME SCALE, AD 1950-500 BC AND 2500-6000 BC}

\author{
MINZE STUIVER
}

Department of Geological Sciences and Quaternary Research Center, University of Washington Seattle, Washington 98195 USA

and

\section{GORDON W. PEARSON}

Retired from Palaeoecology Centre, The Queen's University of Belfast, Belfast, BT71NN, Northern Ireland

\section{INTRODUCTION}

The radiocarbon ages of dendrochronologically dated wood spanning the AD 1950-6000 BC interval are now available for Seattle (10-yr samples, Stuiver \& Becker 1993) and Belfast (20-yr samples, Pearson, Becker \& Qua 1993; Pearson \& Qua 1993). The results of both laboratories were previously combined to generate a bidecadal calibration curve spanning nearly 4500 years (Stuiver \& Pearson 1986; Pearson \& Stuiver 1986). We now find that minor corrections must be applied to the published data sets, and therefore, give new bidecadal radiocarbon age information for 2500-6000 BC, as well as corrected radiocarbon age averages for $\mathrm{AD} 1950-500 \mathrm{BC}$. Corrected average ${ }^{14} \mathrm{C}$ ages for the 500-2500 BC interval are given separately (Pearson \& Stuiver 1993). The Seattle corrections (in the $10-30{ }^{14} \mathrm{C}$-yr range) are discussed in Stuiver and Becker (1993), whereas Pearson and Qua (1993) provide information on Belfast corrections (averaging $16 \mathrm{yr}$ ). All dates reported here are conventional radiocarbon dates, as defined in Stuiver and Polach (1977). Belfast ${ }^{14} \mathrm{C}$ ages back to $5210 \mathrm{BC}$ were obtained on wood from the Irish oak chronology (Pearson et al. 1986). Wood from the German oak chronology (Becker 1993) was used by Belfast for the 5000-6000 BC interval. For the overlapping interval (5000-5210 BC), Belfast reports weighted Irish wood/German wood ${ }^{14} \mathrm{C}$ age averages. The Seattle ${ }^{14} \mathrm{C}$ ages for the $\mathrm{AD}$ interval were either on Douglas fir wood from the US Pacific Northwest, or Sequoia wood from California (Stuiver 1982). The BC materials measured in Seattle were mostly part of the German oak chronology. Thirteen samples (5680-5810 BC) from the US bristlecone pine chronology (Ferguson \& Graybill 1983) were measured in Seattle as well. Here, the final Seattle decadal ${ }^{14} \mathrm{C}$ ages resulted from averaging German oak and bristlecone pine ages.

Several factors contribute to the uncertainty in the calibration curve for bidecadal cellulose samples. The precision and accuracy of the ${ }^{14} \mathrm{C}$ measuring process is limited, and dendrochronological errors (if any) may result in ${ }^{14} \mathrm{C}$ age differences when materials of different chronologies (and "identical" $\mathrm{AD}$ or $\mathrm{BC}$ age) are used. And although relatively fast transport in the troposphere causes atmospheric ${ }^{14} \mathrm{CO}_{2}$ to be fairly uniformly mixed near the earth surface, small regional differences remain. General circulation and carbon reservoir model calculations (Braziunas, Fung \& Stuiver 1991) predict regional "age" differences of maximally $20{ }^{14} \mathrm{C}$ years within the northern hemisphere. 
Such inhomogeneity in atmospheric ${ }^{14} \mathrm{CO}_{2}$ alone can induce ${ }^{14} \mathrm{C}$ age offsets on the order of a decade between individual northern hemisphere dendrochronologies.

The Seattle and Belfast results on wood of the same calibrated (cal) age, but not necessarily of the same region, give consistent replication for most of the 8000-yr record. Marginal replication is only encountered for the 5180-5500 BC interval. We first discuss the aspects of replication; detailed calibration curves follow.

\section{SAMPLE AVAILABILITY AND PRETREATMENT}

During the earlier phases of the Seattle calibration project, many of the wood samples of $\mathrm{AD}$ age were treated with dilute $\mathrm{NaOH}$ and $\mathrm{HCl}$ solutions to remove resins, sugars and a portion of the lignin (de Vries method, Stuiver \& Quay 1980). The samples from the German chronology (and part of our single-year AD Pacific Northwest chronology) were subjected to a more rigorous extraction, yielding alpha cellulose. The cellulose preparation procedure is similar to the ${ }^{13} \mathrm{C}$ sample treatment given in Stuiver, Burk \& Quay (1984), with slight modifications due to the bulk of the ${ }^{14} \mathrm{C}$ samples. The de Vries method is less efficient in removing components added after the year of growth, but the influence of the incomplete removal on the ${ }^{14} \mathrm{C}$ ages of the Seattle samples is limited to 2 or $3{ }^{14} \mathrm{C}$ years (Stuiver \& Quay 1981). All Belfast samples were pretreated to reduce the wood to cellulose (Pearson \& Stuiver 1986).

To cover identical bidecades for Belfast and Seattle, we combined pairs of Seattle decadal ${ }^{14} \mathrm{C}$ (weighted mean) to produce appropriate bidecadal results. The sequence is not entirely a rhythmic flow of numbers because there are a few 10-yr gaps in the Belfast bidecadal sequence, some overlapping bidecadal measurements with a 10 -yr difference at midpoint, and some missing Seattle and Belfast measurements. Many samples had to be processed, and occasionally, wood was either not available in sufficient quantities (thin rings) for the high-precision ${ }^{14} \mathrm{C}$ measurement, or was lost during sample processing. There are also small differences in midpoint age of the "contemporaneous" 20 -yr blocks used for ${ }^{14} \mathrm{C}$ age averaging of up to 2 cal yr. Thus, the listed midpoint cal ages (which are multiples of 10, with exceptions listed below) can differ by up to $1 \mathrm{cal}$ yr from the actual cal age. The following exceptions apply (dates given are midpoints):
AD 1940-1860
AD 1825/AD 1275/AD 1245
Seattle bidecadal data only
Seattle decadal points inserted in Belfast data
gaps
AD 1212/AD 1192/AD 952
Averages of bidecades with midpoints $5 \mathrm{yr}$ apart
$2450 \mathrm{BC} / 4150 \mathrm{BC} / 5150 \mathrm{BC}$
Belfast data only, as in each case one of the
Seattle decadal measurements was missing.

\section{TECHNIQUE AND LABORATORY REPRODUCIBILITY}

The radiocarbon community tends to under-report the standard error in a ${ }^{14} \mathrm{C}$ age determination (International Study Group 1982; Scott, Long \& Kra 1990). Age errors solely based on the Poisson error in the number of counts accumulated during the ${ }^{14} \mathrm{C}$ activity measurement are lower limits only, and an "error multiplier" $\mathrm{K}$ (defined as the actual standard error/quoted standard error) must be applied (e.g., Stuiver 1982). The error multiplier of a specific laboratory may range from 1 to 2 (Scott, Long \& Kra 1990). Although the sources of variance are additive (causing $\mathrm{K}$ to increase with sample age), $\mathrm{K}$ is a convenient expression of the degree to which the quoted error is representative of the overall error in a ${ }^{14} \mathrm{C}$ date. 
The quoted standard errors of the Belfast laboratory are based on a study of the parameters contributing to the error in ${ }^{14} \mathrm{C}$ measurements of the liquid scintillation counting system employed (Pearson et al. 1986), whereas for Seattle's $\mathrm{CO}_{2}$ gas counting system, the quoted errors are based on the Poisson standard deviation in the sample count and the largest of 1) the Poisson deviation in the average of multiple standard runs, and 2) the standard deviation from the observed scatter in these multiple runs. Previous replicate analysis of 55 determinations on pairs of wood of the same age yielded $\mathrm{K}_{\text {Beffast }}=1.23$ (Pearson et al. 1986), whereas the upper limit for $\mathrm{K}_{\text {Seatle }}$ was estimated at 1.6 (Stuiver \& Pearson 1986; Stuiver \& Becker 1993).

\section{SYSTEMATIC DIFFERENCES BETWEEN LABORATORIES}

Interlaboratory comparisons are needed to identify any offsets, and these lead to independent $\mathrm{K}$ information as well. We compared the ${ }^{14} \mathrm{C}$ age results (Kromer et al. 1986; Kromer \& Becker 1993; de Jong, Becker \& Mook 1986; Linick et al. 1986; Pearson, Becker \& Qua 1993; Pearson \& Qua 1993; Stuiver \& Becker 1993, Vogel et al. 1993) of dendrochronologically dated wood of the same age and different origin, as well as those of the same age and same chronology.

Of the six laboratories involved, three measured either decadal (Tucson and Seattle) or bidecadal samples (Belfast). Groningen, Heidelberg and La Jolla measured samples grown over shorter time intervals (usually 1-3 yr). For comparison purposes, we choose to average the published results over decades or bidecades. Usually only part of the 10 or 20 years will have been measured, and the "decadal" or "bidecadal" ${ }^{14} \mathrm{C}$ ages calculated in this manner need not be identical to the ${ }^{14} \mathrm{C}$ ages that would have been obtained by measuring decadal or bidecadal samples directly. An error multiplier, $\mathrm{K}_{\mathrm{Lab} A-\mathrm{Lab} B}$, for interlaboratory comparisons was derived by taking the quotient of the standard deviation, $\sigma_{\mathrm{tot}}$, in the observed differences and the average standard deviation, $\sigma$, of the differences calculated from the quoted errors in the ${ }^{14} \mathrm{C}$ determinations.

A test of internal consistency of ${ }^{14} \mathrm{C}$ data of laboratories measuring wood of the same tree chronology provides insight into the sum total uncertainty tied to procedures of wood allocation, dendro-age determination, sample pretreatment, laboratory ${ }^{14} \mathrm{C}$ determination, regional ${ }^{14} \mathrm{C}$ distribution and ${ }^{14} \mathrm{C}$ differences between individual trees of the same chronology. Often the splitting of samples from wood sections in the dendrochronology laboratories took place several years apart, and wood from identical trees was not necessarily supplied for the same chronology to different ${ }^{14} \mathrm{C}$ laboratories. Here, even the region may be uncertain, because the area of original growth is not well defined for trees collected from alluvial sediments.

Good interlaboratory ${ }^{14} \mathrm{C}$ age agreement $(\mathrm{n}=$ number of comparisons, offset $=$ "a" with positive values when Lab A dates are older) is found, e.g., for decadal or bidecadal wood (in some instances, "decadal" or "bidecadal", see above) of the German chronology (Becker 1993) with $\mathrm{K}_{\text {Seattle-Groningen }}=1.8$ and $\mathrm{a}=-4 \pm 2 \mathrm{yr}(3210-3910 \mathrm{BC}, \mathrm{n}=36), \mathrm{K}_{\text {Seattle-Pretoria }}=1.2$ and $\mathrm{a}=4 \pm 2$ $\mathrm{yr}(1930-3350 \mathrm{BC}, \mathrm{n}=72), \mathrm{K}_{\text {Seattle-La Jolla }}=1.3$ and $\mathrm{a}=-4 \pm 3$ yr $(2500-5000 \mathrm{BC}, \mathrm{n}=97)$, and $\mathrm{K}_{\text {Seattle-Belfast }}=1.5$ and $\mathrm{a}=-15 \pm 4 \mathrm{yr}(5500-6000 \mathrm{BC}, \mathrm{n}=24)$. Less satisfactory agreement is found in $\mathrm{K}_{\text {Seattle-Belfast }}=1.3$ and $\mathrm{a}=-54 \pm 5 \mathrm{yr}(5180-5500 \mathrm{BC}, \mathrm{n}=16)$ and $\mathrm{K}_{\text {Seatle-Heidelberg }}=1.8$ and $\mathrm{a}=$ $-41 \pm 4 \mathrm{yr}(4075-5265 \mathrm{BC}$ and $5805-5995 \mathrm{BC}, \mathrm{n}=65)$. The reasons for the larger offsets are, as yet, not well understood.

Comparing decadal or bidecadal ${ }^{14} \mathrm{C}$ dates from the German (measured in Seattle and Belfast) and bristlecone pine (measured in Tucson and Seattle) chronologies for the 5680-5810 BC interval yields excellent agreement with $\mathrm{K}_{\text {Seattle-Seatle }}=1.3$ and $\mathrm{a}=-6 \pm 7 \mathrm{yr}(\mathrm{n}=13), \mathrm{K}_{\text {Seattle-Tucson }}=1.8$ and $\mathrm{a}=-3 \pm 7 \mathrm{yr}(\mathrm{n}=15$; the 2 additional points are at 6475 and $6360 \mathrm{BC})$, and $\mathrm{K}_{\text {Belfast-Tucson }}=1.8$ and $a=6 \pm 7(n=7)$. A comparison of the joint Northwest Pacific and German chronology measured 
in Seattle, and the Irish chronology measured in Belfast, yielded, for bidecadal samples covering the $\mathrm{AD} 1840-5180 \mathrm{BC}$ interval $\mathrm{K}_{\text {Seatle-Belfast }}=1.56$ and $\mathrm{a}=2 \pm 1(\mathrm{n}=344)$. The majority of offsets are in the decade (or less) range, and error multipliers for the age differences are 1.8 maximally.

Of crucial importance for the construction of the bidecadal calibration curve are the systematic differences between Seattle and Belfast results for the AD 1840-6000 BC interval. The systematic difference, averaging only $-0.8 \pm 0.9 \mathrm{yr}(\mathrm{K}=1.7, \mathrm{n}=386)$ for the full $\mathrm{AD} 1840-6000 \mathrm{BC}$ interval, can be substantially larger for shorter time units. Systematic differences for successive millennia (first "millennium" is AD 1840-1000, last one 5001-6000 BC) are $-0.4 \pm 2.3 \mathrm{yr}(\mathrm{K}=1.4), 0.9 \pm$ $2.6(\mathrm{~K}=1.4), 9.9 \pm 2.5(\mathrm{~K}=1.3), 16.6 \pm 2.6(\mathrm{~K}=1.4), 2.4 \pm 2.4(\mathrm{~K}=1.8),-4.3 \pm 2.6(\mathrm{~K}=1.4)$, $-12.1 \pm 2.8(\mathrm{~K}=1.9)$ and $-25.2 \pm 2.7(\mathrm{~K}=1.7)$. These offsets (applying the corresponding $\mathrm{K}$ value) equal, respectively, $0.1,0.2,3.0,4.6,0.1,1.2,2.3$ and 5.3 times the standard deviation in the mean. Clearly, the $9.9(3.0 \sigma), 16.6(4.6 \sigma)$ and $-25.2(5.3 \sigma){ }^{14} \mathrm{C}$ year offsets are too large to be accounted for solely by statistical considerations of the reproducibility of the measurements. Measurements on four duplicate samples (3130 BC, 3190 BC, $3210 \mathrm{BC}$ and $3230 \mathrm{BC}$ ) of the Irish chronology also yielded a substantial offset of $52 \pm 8 \mathrm{yr}$, with Belfast results being older.

Closer inspection of the distribution of the actual ${ }^{14} \mathrm{C}$ age differences of the 3 millennia with statistically unacceptable systematic offsets shows one interval (5180-5500 BC) with substantial Seattle and Belfast ${ }^{14} \mathrm{C}$ age differences $(\mathrm{a}=-54 \pm 5 \mathrm{yr})$. The offset for the remaining portion of the millennium $(5001-5180 \mathrm{BC}$ and $5500-6000 \mathrm{BC})$ is now $-12.2 \pm 3.3 \mathrm{yr}(\mathrm{K}=1.5)$. This offset equals 2.4 standard deviations of the mean, which is not an abnormally large value. Significant systematic Seattle-Belfast differences are then $9.9 \mathrm{yr}$ (1-1000 BC), $16.6 \mathrm{yr}(1001-2000 \mathrm{BC})$ and $-54 \mathrm{yr}(5180-5500 \mathrm{BC})$. The standard deviation given with the calibration curve does not account for offsets. Therefore, for the above intervals, the calibration curve ${ }^{14} \mathrm{C}$ age averages could be subject to systematic errors of, respectively, 5.0, 8.3 and $27 \mathrm{yr}$. The first two systematic errors are rather insignificant, as they are less than a decade and only a fraction of the curve standard deviation (which averages $12.9 \mathrm{yr}$ ). The 27-yr systematic error contribution to the radiocarbon ages of the 5180-5500 BC interval, however, is unacceptably large and warrants further calibration efforts.

\section{CONSTRUCTION OF THE RADIOCARBON AGE CALIBRATION CURVES}

When calculating the Seattle-Belfast bidecadal ${ }^{14} \mathrm{C}$ age averages, and their errors, an error multiplier must be assigned to the quoted laboratory error. In our previous papers, we took $\mathrm{K}_{\text {Belfast }}=1.23$ and $\mathrm{K}_{\text {Seattle }}=1.6$ for results going back to $2500 \mathrm{BC} . \mathrm{K}$ tends to increase with sample age $(e . g$., for the $\mathrm{AD} 1840-2500 \mathrm{BC}$ interval, $\mathrm{K}_{\text {Seattle-Belfast }}=1.44(\mathrm{n}=212, \mathrm{a}=7 \pm 1.2 \mathrm{yr})$, whereas for the 2500$5000 \mathrm{BC}$ interval, $\left.\mathrm{K}_{\text {seattle-Belfast }}=1.75(\mathrm{n}=124, \mathrm{a}=-7 \pm 1.6)\right)$. Thus, we selected a larger $\mathrm{K}$ value of 1.7 for both Seattle and Belfast for samples older than 2500 BC. A more detailed discussion of this choice can be found elsewhere (Stuiver \& Pearson 1992).

The above $\mathrm{K}$ values, multiplied with the quoted standard deviation, yield corrected standard deviations ( $\sigma$ ) for the individual Belfast and Seattle ${ }^{14} \mathrm{C}$ ages. Using these standard deviations, we find that the calculated standard deviations of the ${ }^{14} \mathrm{C}$ age differences of contemporaneous bidecadal sample pairs of Seattle and Belfast account for $90-100 \%$ of the demonstrated standard deviations in ${ }^{14} \mathrm{C}$ age differences of both laboratories for the $\mathrm{AD} 1940-5180 \mathrm{BC}$ and $5500-6000 \mathrm{BC}$ intervals. The standard deviations of the weighted average ${ }^{14} \mathrm{C}$ ages (Table 1 ) of sample pairs that form the basis of the ${ }^{14} \mathrm{C}$ calibration curve are based on the above K-corrected standard deviations.

The mean standard deviation of the bidecadal averages of Seattle and Belfast is $12.9( \pm 1.6 \%$ for $\left.\Delta \Delta^{14} \mathrm{C}\right){ }^{14} \mathrm{C}$ yr for the $\mathrm{AD} 1950-6000 \mathrm{BC}$ interval. The standard deviations of the ${ }^{14} \mathrm{C}$ ages associated 
with the 5180-5500 BC interval do not fully account for the total uncertainty, as systematic error contributions play a role for this part of the calibration curve (see previous section).

\section{CALIBRATION INSTRUCTIONS}

We recommend that users of ${ }^{14} \mathrm{C}$ dates obtain additional information on reproducibility (and systematic error, if any) from the laboratory reporting the ${ }^{14} \mathrm{C}$ date. This information should lead to a realistic standard deviation in the reported age. A systematic error has to be deducted from, or added to, the reported radiocarbon age prior to age calibration.

Only the calibration curve is given in Figure 1; the one-sigma ( $1 \sigma$; standard deviation) uncertainty in the curve is not given. The actual standard deviation (averaging $12.9{ }^{14} \mathrm{C} \mathrm{yr}$ for the nearly 8000 cal yr bidecadal calibration curve of Seattle-Belfast ${ }^{14} \mathrm{C}$ age averages) is tabulated in Table 1 for each bidecadal midpoint.

$\mathrm{Cal} \mathrm{BP}$ ages are relative to the year $\mathrm{AD} 1950$, with 0 cal $\mathrm{BP}$ equal to $\mathrm{AD} 1950$. The relationship between cal AD/BC and cal BP ages is cal $\mathrm{BP}=1950-\mathrm{cal} \mathrm{AD}$, and cal BP $=1949+\mathrm{cal} \mathrm{BC}$. The switch from 1950 to 1949 when converting $\mathrm{BC}$ ages is caused by the absence of the year zero in the $\mathrm{AD} / \mathrm{BC}$ chronology.

The conversion of a ${ }^{14} \mathrm{C}$ age to a cal age is as follows: 1) draw line A parallel to the bottom axis through the ${ }^{14} \mathrm{C}$ age to be converted; 2) draw vertical line(s) through the intercept(s) of line $\mathrm{A}$ and the calibration curve. The cal $\mathrm{AD} / \mathrm{BC}$ ages can be read at the bottom axis, the cal $\mathrm{BP}$ ages at the top.

To convert the standard error in the ${ }^{14} \mathrm{C}$ age into a range of $\mathrm{cal} A \mathrm{AD} / \mathrm{BC}$ (BP) ages, determine the sample standard deviation, $\sigma$, by multiplying the quoted laboratory standard deviation with the "error multiplier." Unfortunately, information on error multipliers is often lacking. Here, the ${ }^{14} \mathrm{C}$ age user should refer to K values given above, or to Scott, Long \& Kra (1990).

Once the sample $\sigma$ is known, the curve $\sigma$ should be read from Table 1 . The curve $\sigma$ and sample $\sigma$ should then be used to calculate total $\sigma=\left((\text { sample } \sigma)^{2}+(\text { curve } \sigma)^{2}\right)^{1 / 2}$ (Stuiver 1982). Lines parallel to A should now be drawn through the ${ }^{14} \mathrm{C}$ age + total $\sigma$, and ${ }^{14} \mathrm{C}$ age - total $\sigma$ value. The vertical lines drawn through the intercepts now yield the outer limits of possible cal $\mathrm{AD} / \mathrm{BC}$ (cal BP) ages that are compatible with the sample standard deviation.

The conversion procedure yields 1 ) single or multiple cal $\mathrm{AD} / \mathrm{BC}(\mathrm{BP})$ ages that are compatible with a certain ${ }^{14} \mathrm{C}$ age, and 2) the range(s) of cal ages that correspond(s) to the standard deviation in the ${ }^{14} \mathrm{C}$ age (and calibration curve). Here, the user must determine the calibrated ages from Figure 1 graphs by drawing lines, whereas an alternate approach would be to use the computerized calibration (CALIB) program discussed elsewhere in this issue (Stuiver \& Reimer 1993).

The probability that a certain cal age is the actual sample age may be quite variable within the cal age range. Higher probabilities are encountered around the intercept ages. The non-linear transform of a near-Gaussian distribution around a ${ }^{14} \mathrm{C}$ age into cal $\mathrm{AD} / \mathrm{BC}$ (cal BP) age is not a simple matter, and computer programs are needed to derive the complex probability distribution. The CALIB program incorporates such probability distributions.

The calibration data presented here are valid for northern hemispheric samples that were formed in equilibrium with atmospheric ${ }^{14} \mathrm{CO}_{2}$. Systematic age differences are possible for the southern hemisphere, where ${ }^{14} \mathrm{C}$ ages of wood samples tend to be about $40 \mathrm{yr}$ older (Vogel et al. 1993). Thus, ${ }^{14} \mathrm{C}$ ages of southern hemispheric samples preceding our era of fossil-fuel combustion should be reduced by $40 \mathrm{yr}$ before conversion into cal $\mathrm{AD} / \mathrm{BC}(\mathrm{BP})$ ages. 
The Figure 1 calibration points are the midpoints of wood samples spanning $20 \mathrm{yr}$. Samples submitted for dating may cover shorter or longer intervals. The decadal calibration results of the Seattle laboratory (Stuiver \& Becker 1993; Stuiver \& Reimer 1993) provide a better time resolution, whereas the CALIB program also has an option to use Figure 1 moving averages (e.g., a 5-point or 100-yr moving average of the bidecadal curve). The latter should be used for a sample grown over a 100 -yr interval. Samples formed over intervals longer than a decade or bidecade are very desirable, as the ${ }^{14} \mathrm{C}$ "wiggles" of the calibration curve have lesser influence on the (midpoint) cal age when a smoothed (moving average) calibration curve is used (Stuiver 1992).

The calibration curve is only valid for age conversion of samples that were formed in equilibrium with atmospheric $\mathrm{CO}_{2}$. Conventional ${ }^{14} \mathrm{C}$ ages of materials not in equilibrium with atmospheric reservoirs do not take into account the offset in ${ }^{14} \mathrm{C}$ age that may occur (Stuiver \& Polach 1977). An offset, or reservoir deficiency, must be deducted from the reported ${ }^{14} \mathrm{C}$ age before any attempt can be made to convert to cal $\mathrm{AD} / \mathrm{BC}(\mathrm{BP})$ ages.

The reservoir deficiency is time dependent for the mixed (and deep) layer of the ocean. For the calibration of marine samples, the reader is referred to Stuiver and Braziunas (1993) and, of course, the CALIB program.

\section{ACKNOWLEDGMENTS}

The ${ }^{14} \mathrm{C}$ research at Seattle and Belfast was supported, respectively, by a National Science Foundation grant BNS-9004492 and a SERC grant. We thank Dr. B. Becker of the University of Hohenheim, Stuttgart for providing German oak (unified Donau/Main series) samples, Drs. J. R. Pilcher and M. G. Baillie for wood samples of the Irish chronology, and F. Qua, P. J. Reimer and P. J. Wilkinson for crucial technical and analytical support.

\section{REFERENCES}

Becker, B. 1993 A 11,000-year German oak and pine dendrochronology for radiocarbon calibration. Radiocarbon, this issue.

Braziunas, T. F., Fung, I. Y. and Stuiver, M. 1991 Oceanic and solar forcing of natural geographic variations in atmospheric $\Delta^{14} \mathrm{C}$. Abstract. Radiocarbon 33(2): 180 .

de Jong, A. F. M., Becker, B. and Mook, W. G. 1986 High-precision calibration of the radiocarbon time scale. In Stuiver, M. and Kra, R. S., eds., Proceedings of the 12th International Radiocarbon Conference. Radiocarbon 28(2B): 939-942.

Ferguson, C. W. and Graybill, D. A. 1983 Dendrochronology of bristlecone pine: A progress report. In Stuiver, M. and Kra, R. S., eds., Proceedings of the 11th International Radiocarbon Conference. Radiocarbon 25(2): 287-288.

International Study Group 1982 An inter-laboratory comparison of radiocarbon measurements in tree rings. Nature 298: 619-623.

Kromer, B. and Becker, B. 1993 German oak and pine ${ }^{14} \mathrm{C}$ calibration, 7200-9400 BC. Radiocarbon, this issue.

Kromer, B., Rhein, M., Bruns, M., Schoch-Fischer, H., Münnich, K. O., Stuiver, M. and Becker, B. 1986 Radiocarbon calibration data for the 6th to the 8th millennia BC. In Stuiver, M. and Kra, R. S., eds., Proceedings of the 12th International Radiocarbon Conference. Radiocarbon 28(2B): 954-960.

Linick, T. W., Long, A., Damon, P. E. and Ferguson, C. W. 1986 High-precision radiocarbon dating of bristlecone pine from 6554 to 5350 BC. In Stuiver, M. and Kra, R. S., eds., Proceedings of the 12th International Radiocarbon Conference. Radiocarbon 28(2B): 943-953.

Pearson, G. W., Becker, B. and Qua, F. 1993 Highprecision ${ }^{14} \mathrm{C}$ measurement of German and Irish oaks to show the natural ${ }^{14} \mathrm{C}$ variations from 7890 to 5000 BC. Radiocarbon, this issue.

Pearson, G. W., Pilcher, J. R., Baillie, M. G. L., Corbett, D. M. and Qua, F. 1986 High-precision ${ }^{14} \mathrm{C}$ measurement of Irish Oaks to show the natural ${ }^{14} \mathrm{C}$ variations from AD 1840-5210 BC. In Stuiver, M. and Kra, R. S., eds., Proceedings of the 12th International Radiocarbon Conference. Radiocarbon 28(2B): 911934.

Pearson, G. W. and Qua, F. 1993 High-precision ${ }^{14} \mathrm{C}$ measurement of Irish oaks to show the natural ${ }^{14} \mathrm{C}$ variations from $\mathrm{AD} 1840-5000 \mathrm{BC}-\mathrm{A}$ correction. Radiocarbon, this issue.

Pearson, G. W. and Stuiver, M. 1986 High-precision calibration of the radiocarbon time scale, $500-2500$ 
BC. In Stuiver, M. and Kra, R. S., eds., Proceedings of the 12th International Radiocarbon Conference. Radiocarbon 28(2B): 839-862.

Pearson, G. W. and Stuiver, M.1993 High-precision bidecadal calibration of the radiocarbon time scale, 500-2500 BC. Radiocarbon, this issue.

Scott, E. M., Long, A. and Kra, R., eds., 1990 Proceedings of the International Workshop on Intercomparison of Radiocarbon Laboratories. Radiocarbon 32(3): 253-397.

Stuiver, M. 1982 A high-precision calibration of the AD radiocarbon time scale. Radiocarbon 24(1): 1-26.

1992 How accurate are our chronologies of the past? I: Time warps caused by the transformation of ${ }^{14} \mathrm{C}$ ages. Proceedings of the Dahlem Workshop on Global Changes in the Perspective of the Past. Chichester, John Wiley \& Sons, in press.

Stuiver, M. and Becker, B. 1993 High-precision decadal calibration of the radiocarbon time scale AD 1950$6000 \mathrm{BC}$. Radiocarbon, this issue.

Stuiver, M. and Braziunas, T. F. 1993 Modeling radiocarbon ages of marine samples back to $10,000 \mathrm{BC}$. Radiocarbon, this issue.

Stuiver, M., Burk, R. L. and Quay, P. D. $1984{ }^{13} \mathrm{C} /{ }^{12} \mathrm{C}$ ratios in tree rings and the transfer of biospheric carbon to the atmosphere. Journal of Geophysical Research 89: 11,731-11,748.
Stuiver, M. and Pearson, G. W. 1986 High-precision calibration of the radiocarbon time scale, AD 1950500 BC. In Stuiver, M. and Kra, R. S., eds., Proceedings of the 12th International Radiocarbon Conference. Radiocarbon 28(2B): 805-838.

1992 Calibration of the radiocarbon time scale 2500-5000 BC. In Taylor, R. E., Long, A. and Kra, R. S., eds., Radiocarbon After Four Decades: An Interdisciplinary Perspective. New York: Springer Verlag: 19-33.

Stuiver, M. and Polach, H. 1977 Discussion: Reporting of ${ }^{14} \mathrm{C}$ data. Radiocarbon 19(3): 355-363.

Stuiver, M. and Quay, P. D. 1980 Changes in atmospheric carbon-14 attributed to a variable Sun. Science 207: 11-19.

1981 Atmospheric ${ }^{14} \mathrm{C}$ changes resulting from fossil fuel $\mathrm{CO}_{2}$ release and cosmic ray flux variability. Earth and Planetary Science Letters 53: 349-362.

Stuiver, M. and Reimer, P. J. 1993 Extended ${ }^{14} \mathrm{C}$ data base and revised CALIB radiocarbon age calibration program. Radiocarbon, this issue.

Vogel, J. C., Fuls, A., Visser, E. and Becker, B. 1993 Pretoria calibration curve for short-lived samples, 1930-3350 BC. Radiocarbon, this issue. 


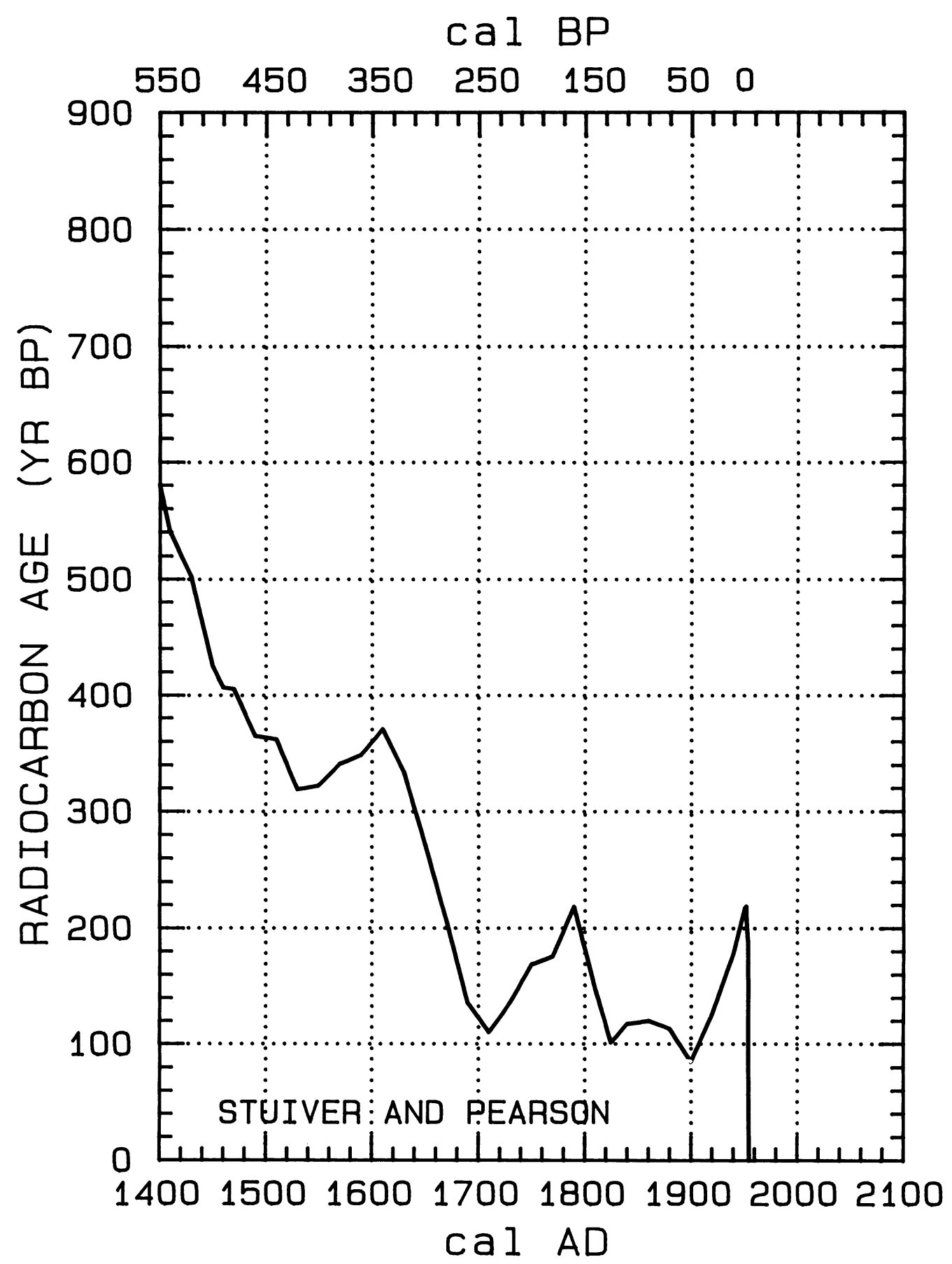

Fig. 1A-L. ${ }^{14} \mathrm{C}$ calibration curve derived from bidecadal samples, with single-year AD 1951-1954 data added to complete the pre-nuclear bomb era 


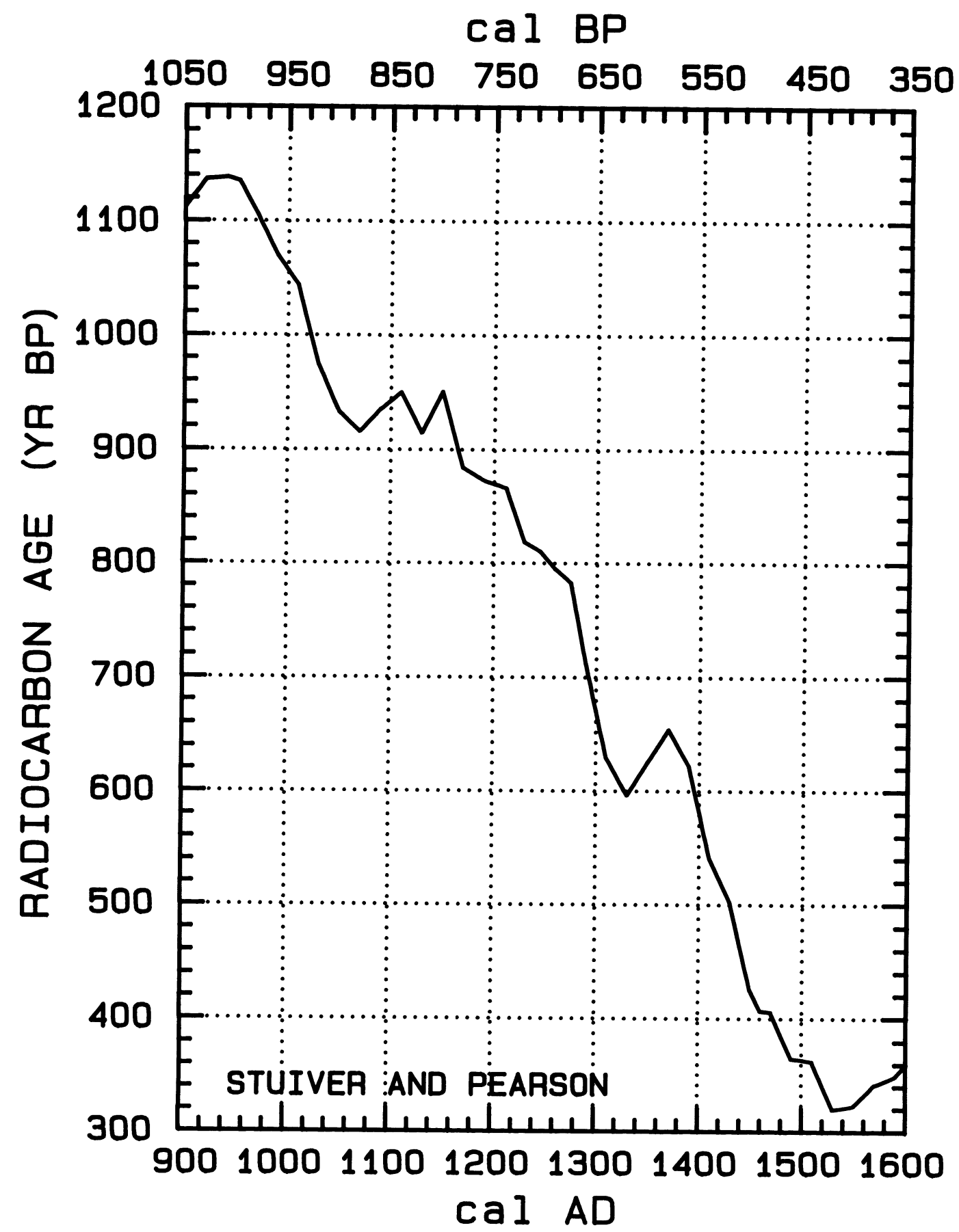

Fig. 1B 


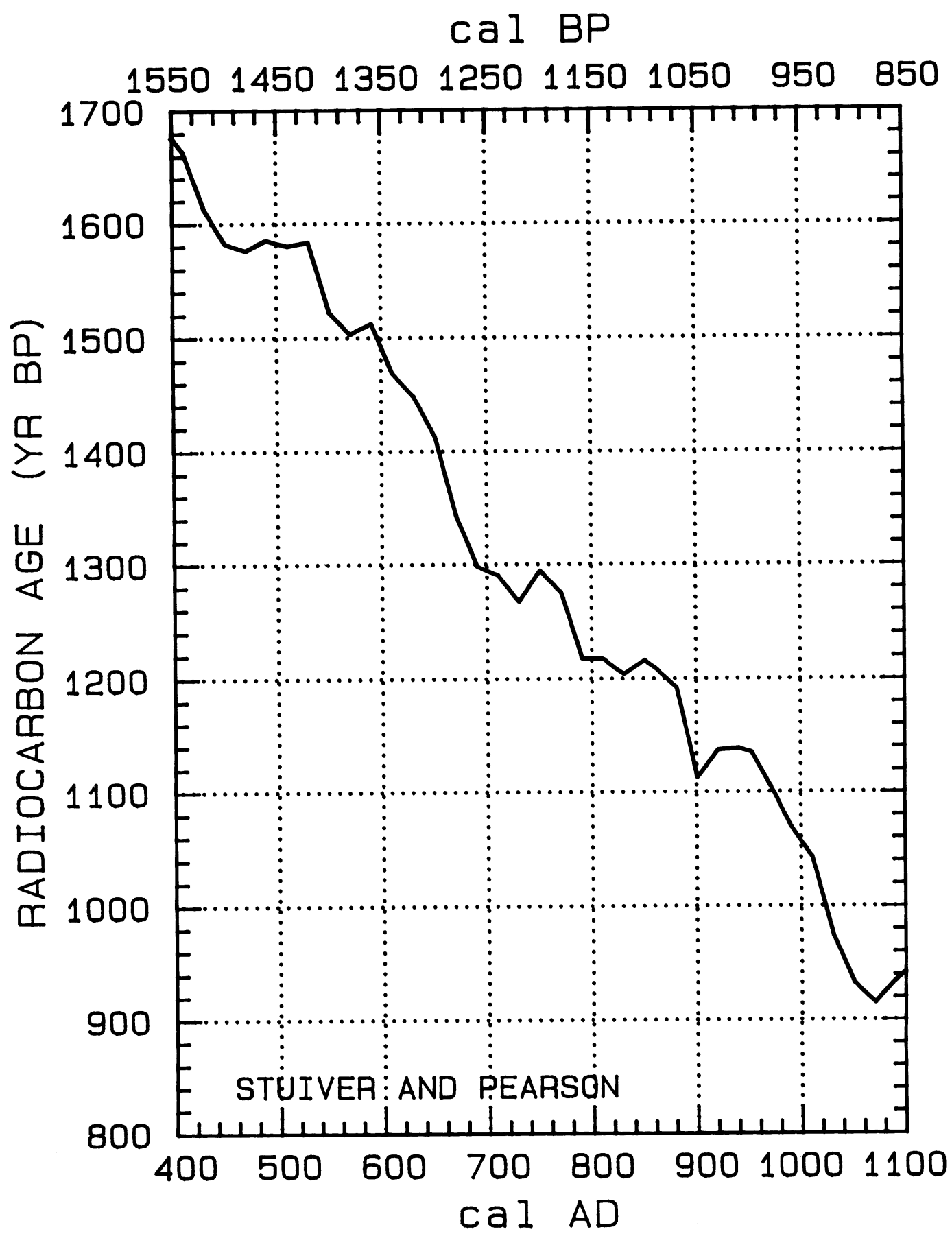

Fig. 1C 


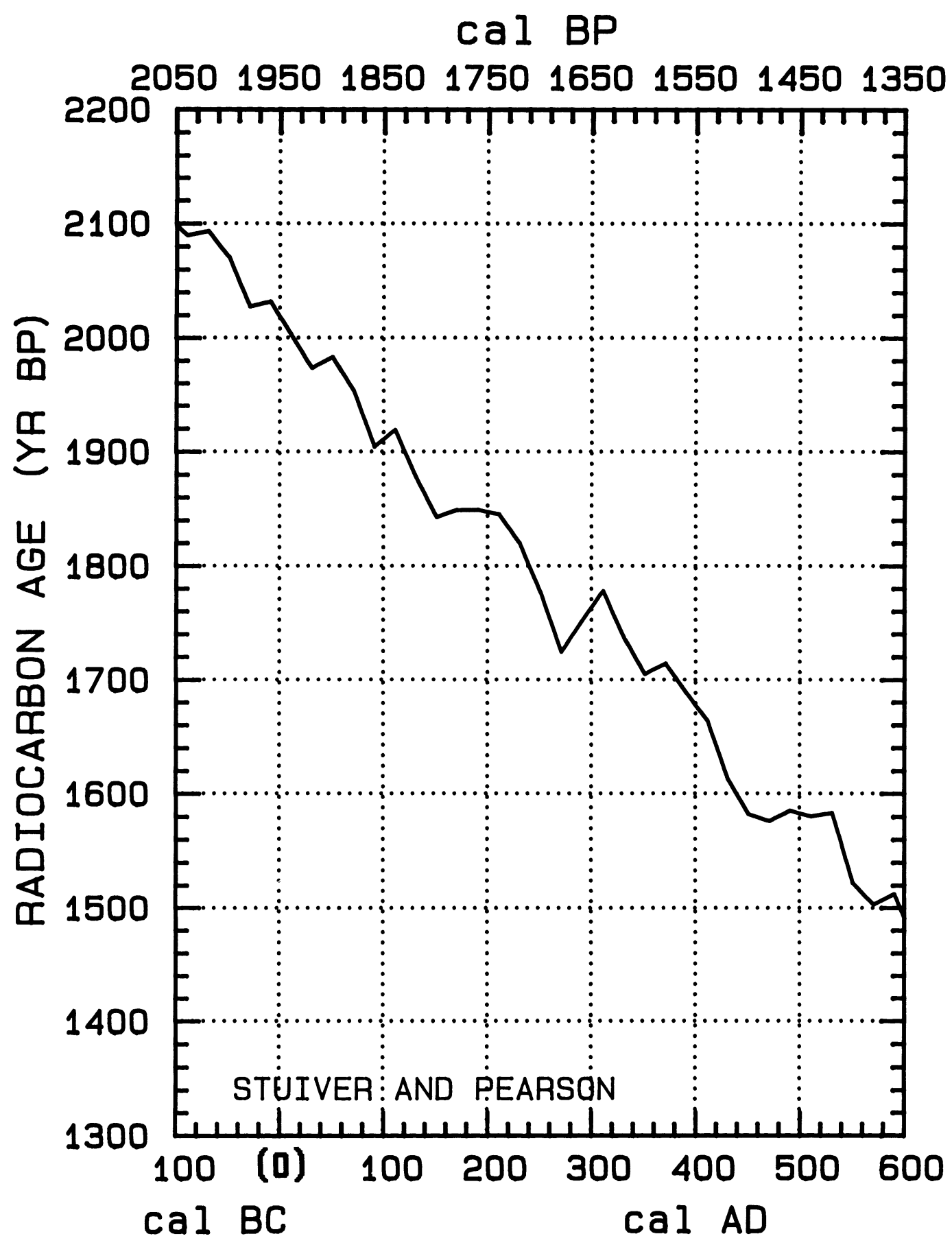

Fig. 1D 


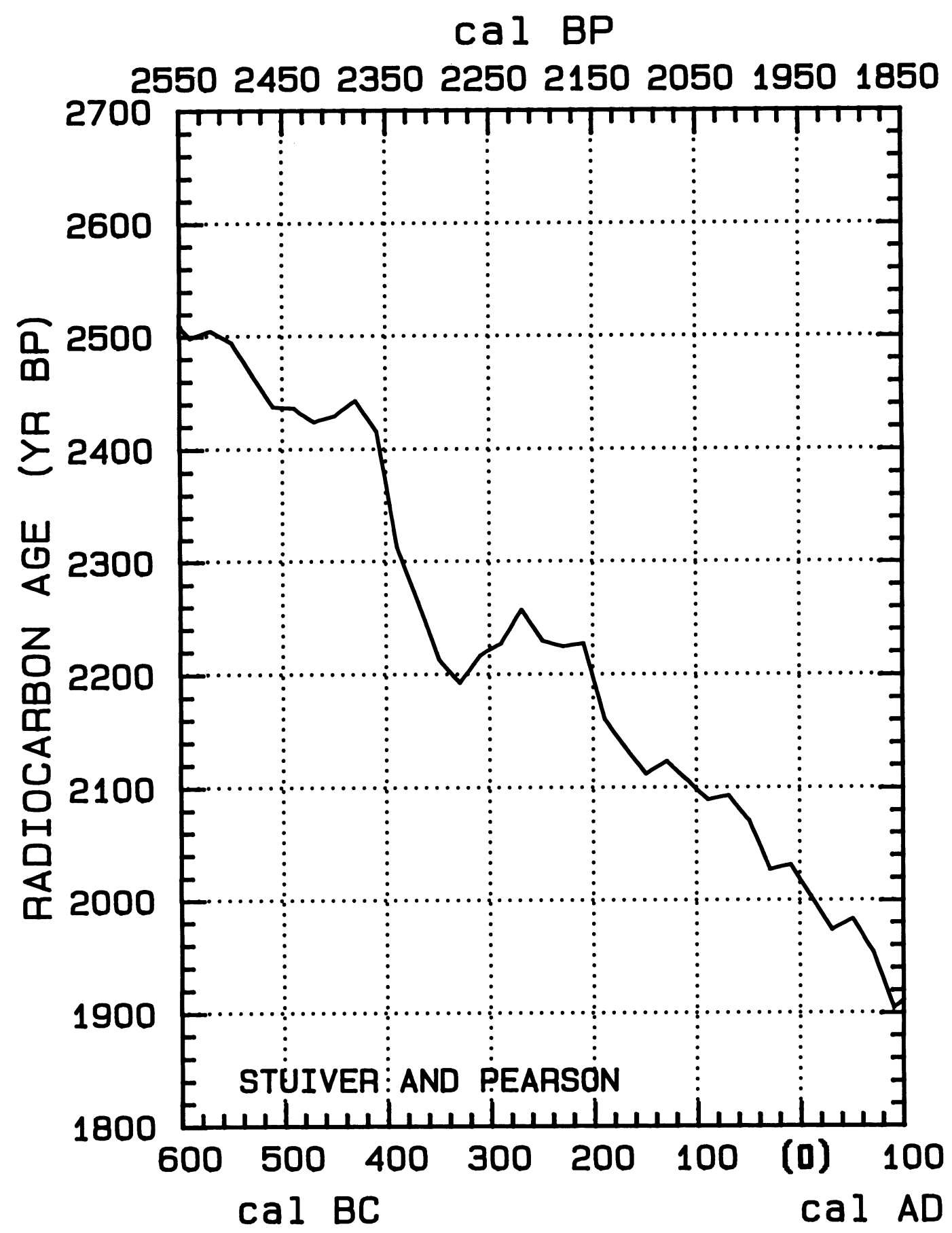

Fig. 1E 


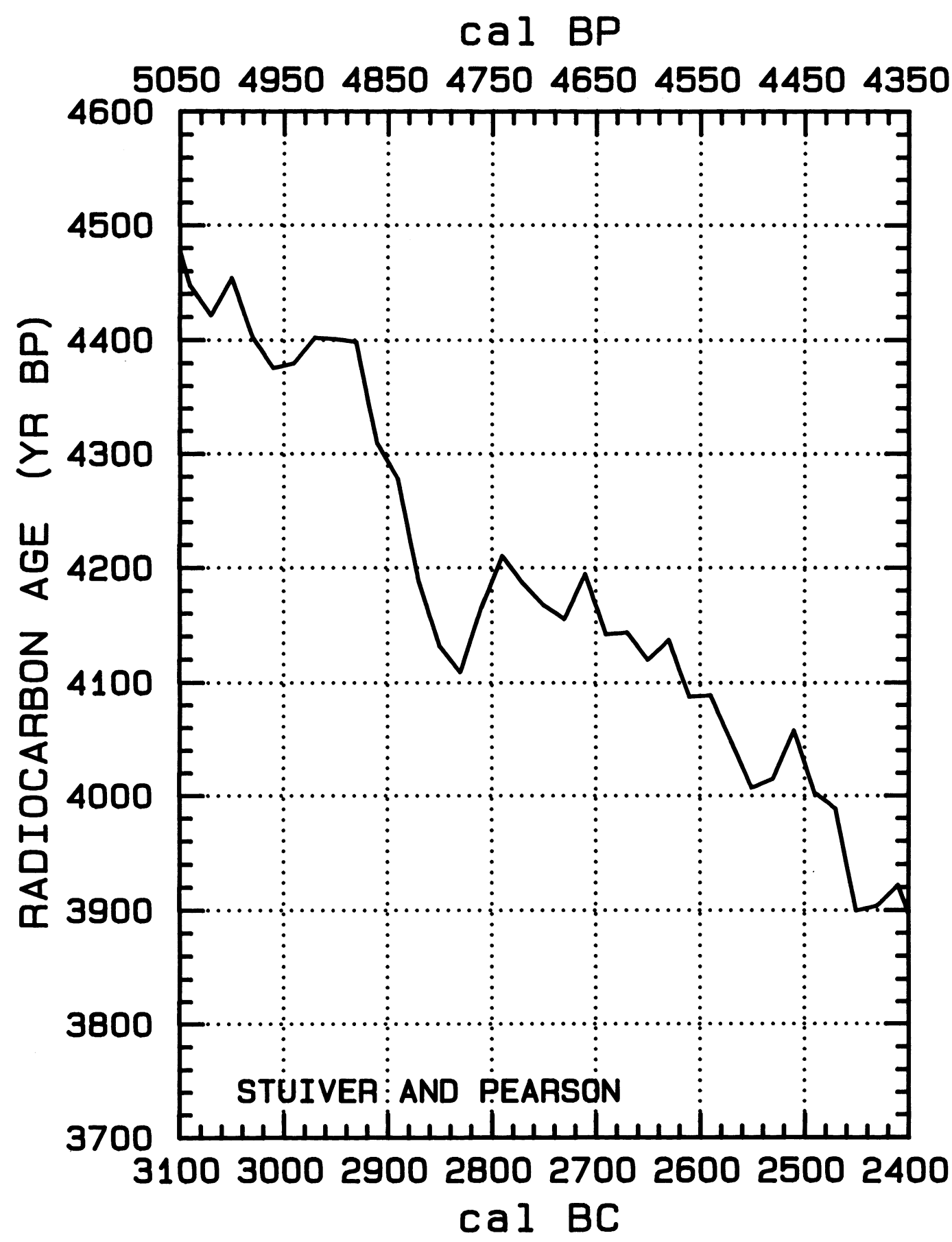

Fig. 1F 


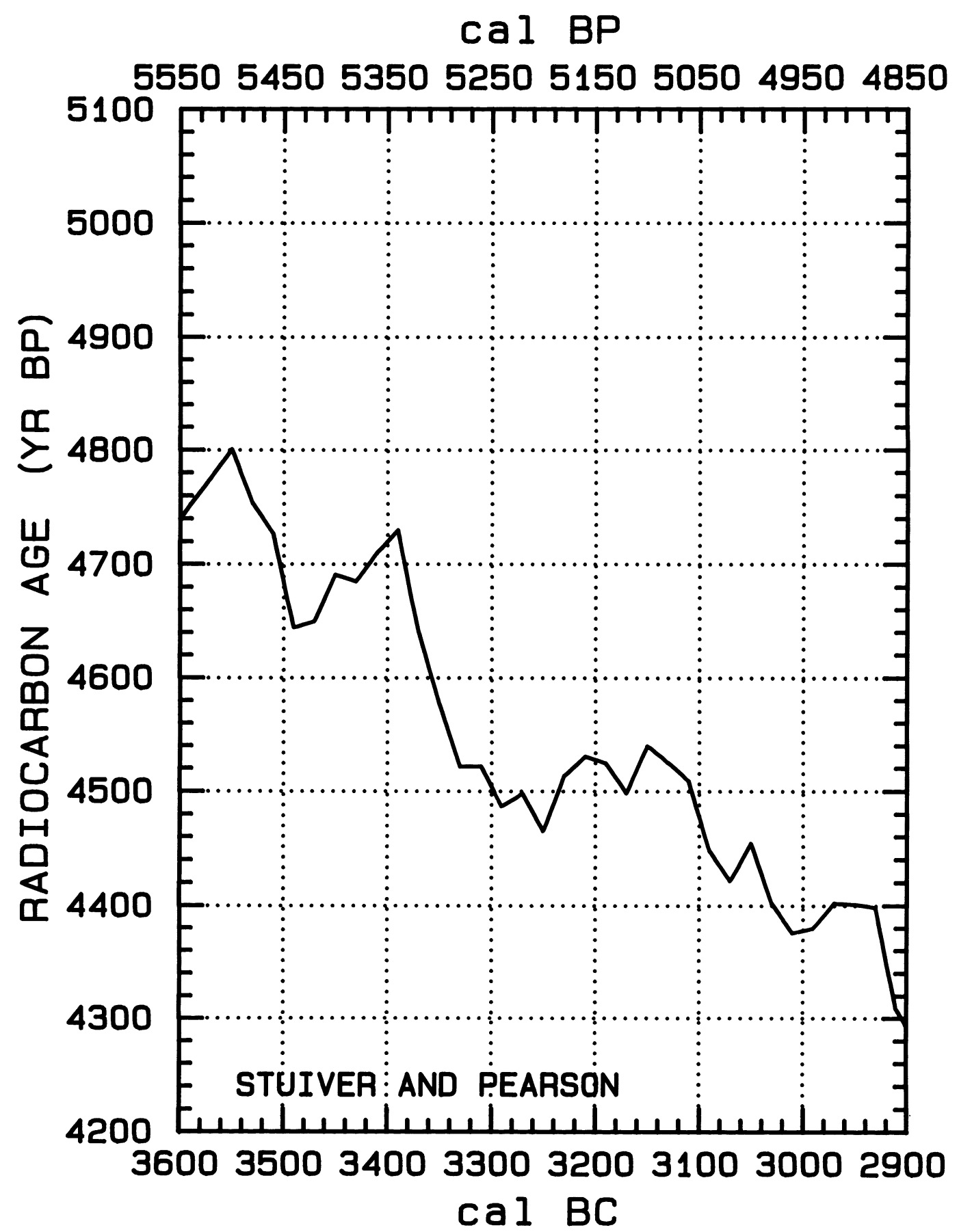

Fig. 1G 


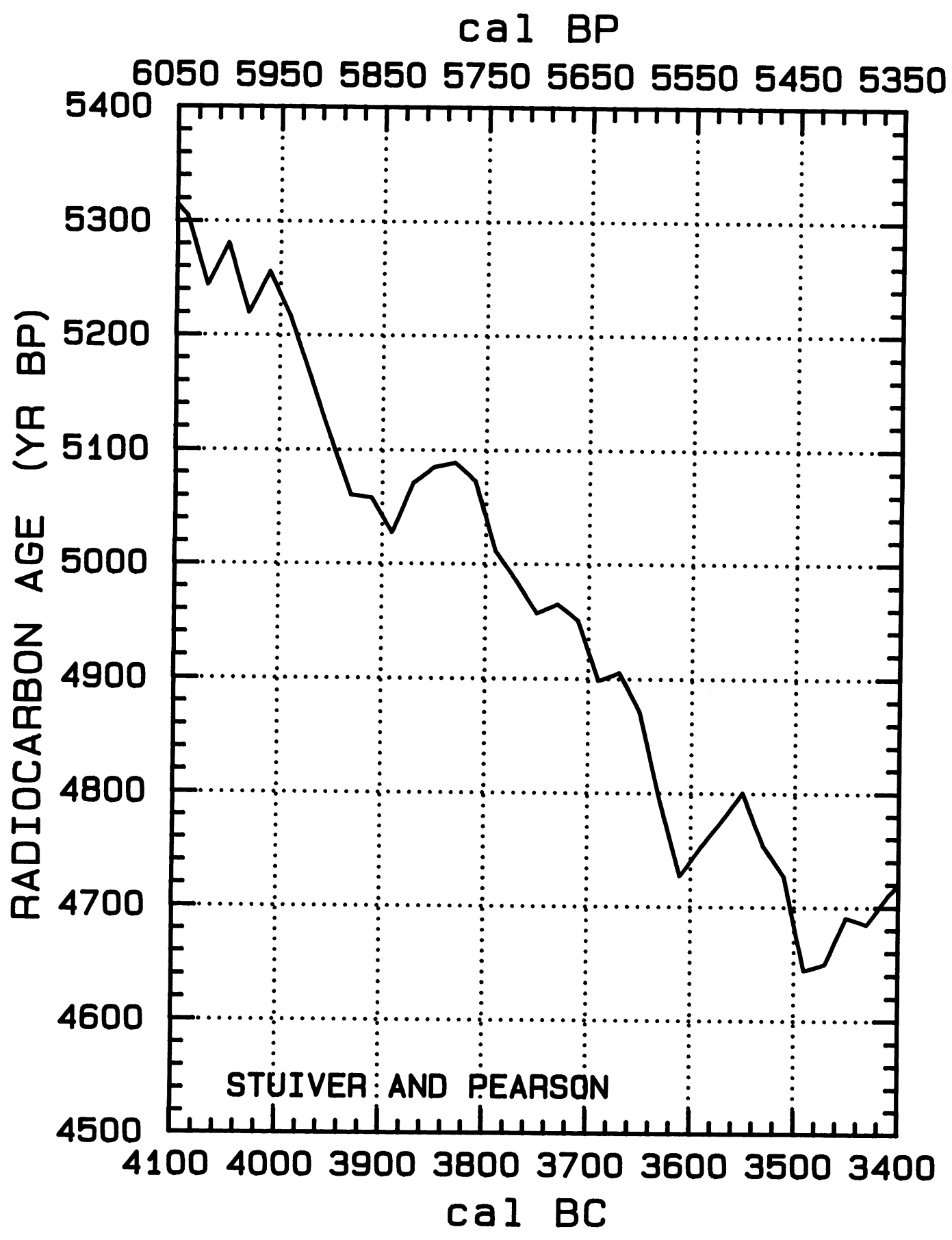

Fig. 1H 


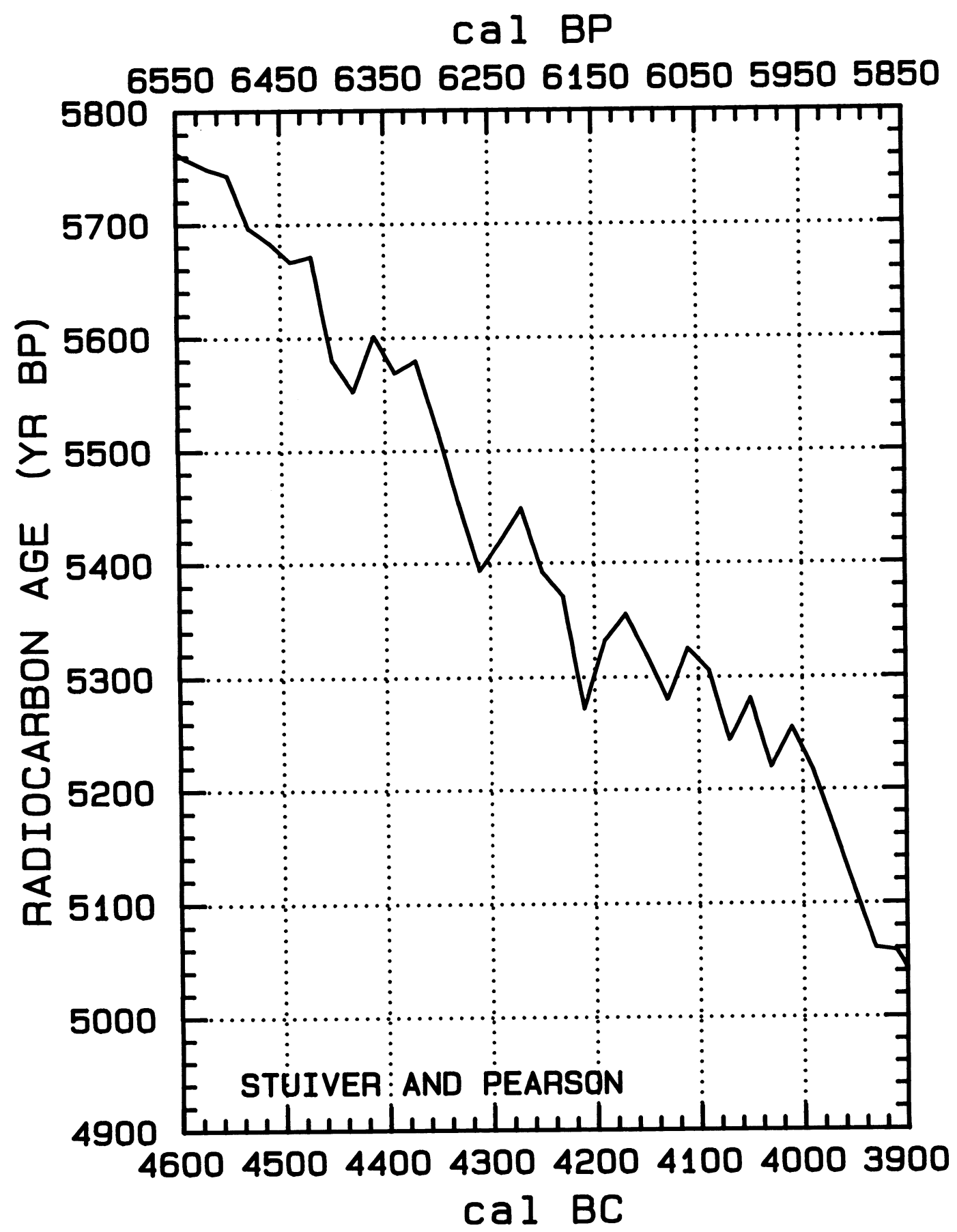

Fig. 1I 


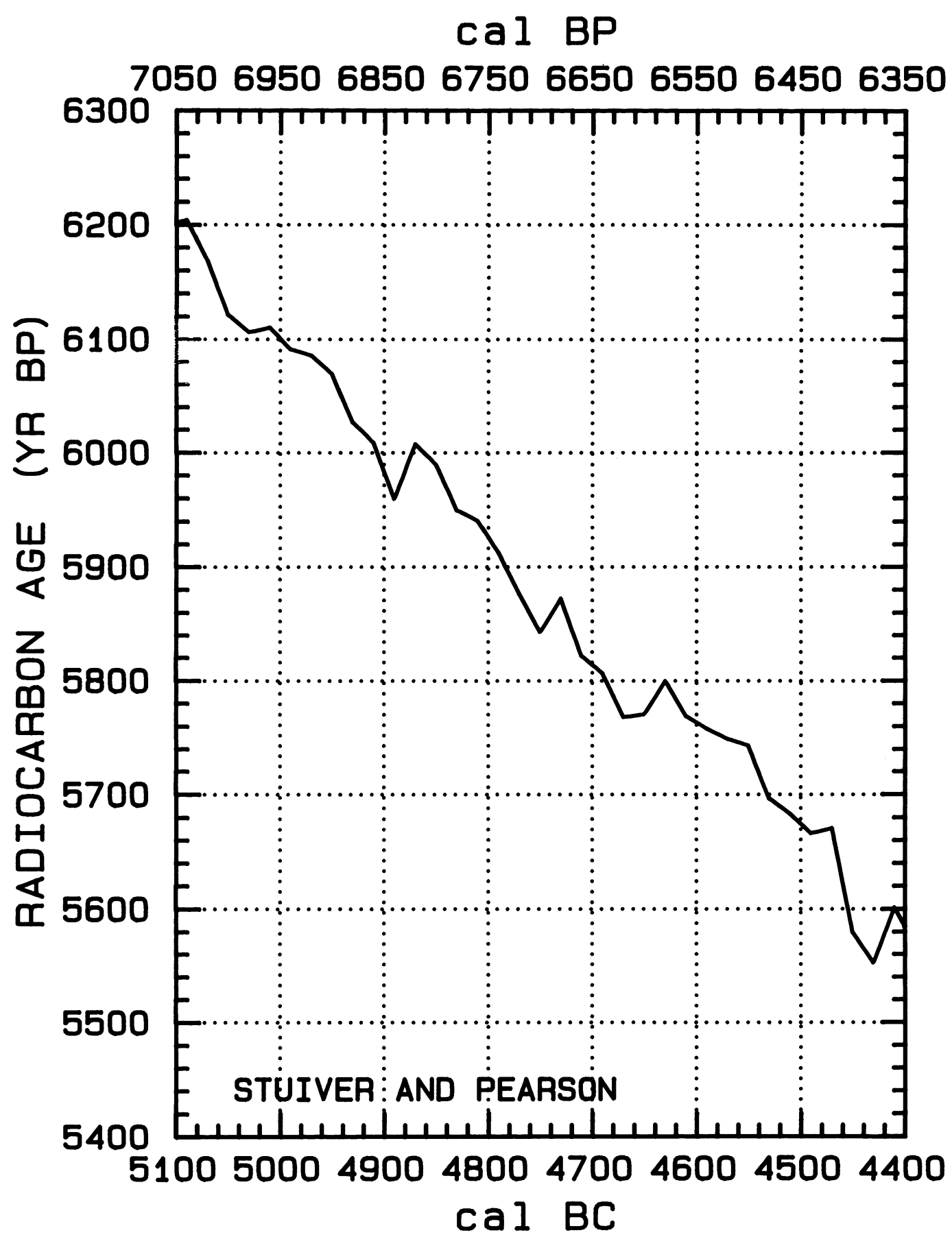

Fig. 1J 


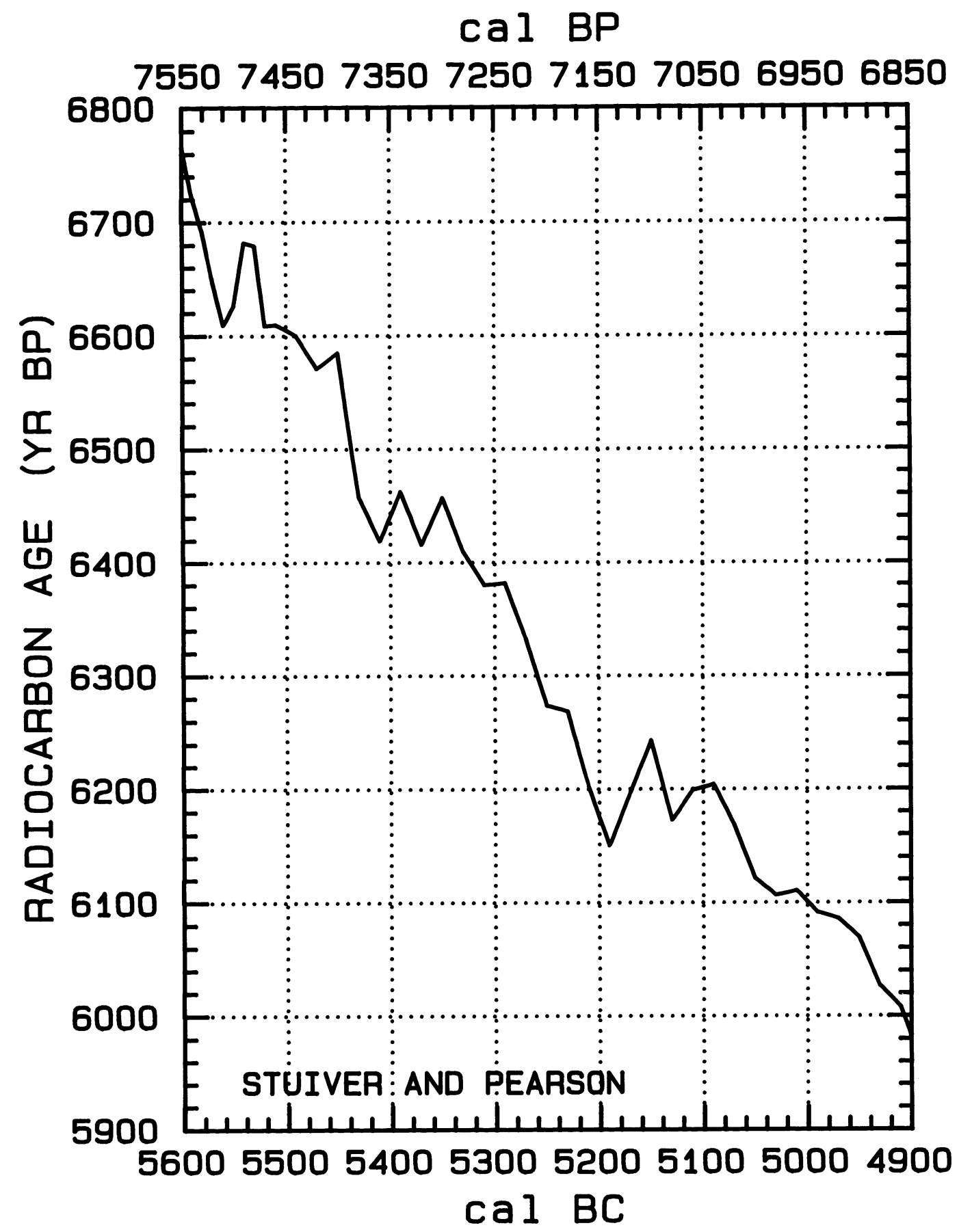

Fig. 1K 


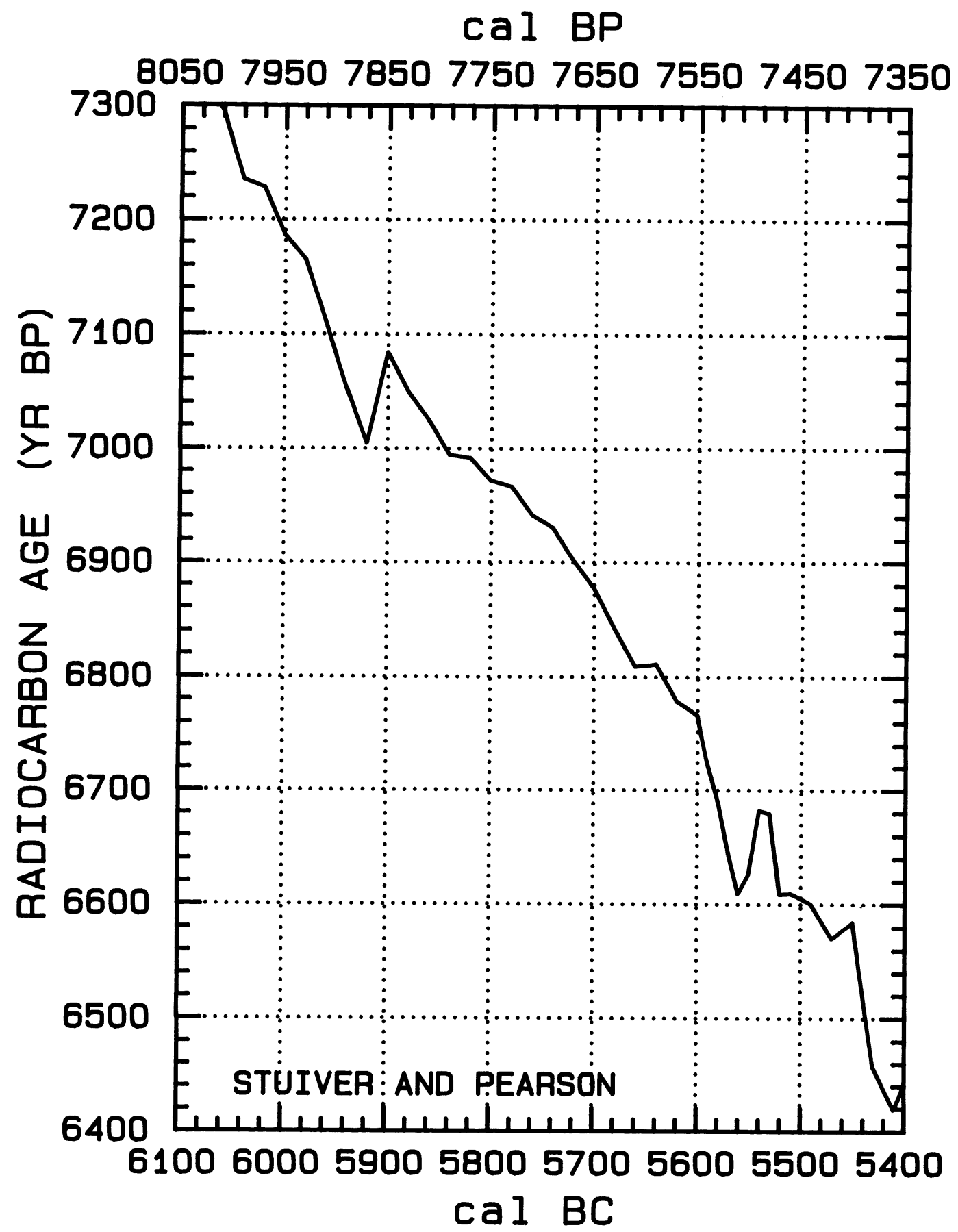

Fig. 1L 
TABLE 1. Weighted averages of University of Washington (Seattle) and the University of Belfast ${ }^{14} \mathrm{C}$ age determinations. The cal $\mathrm{AD} / \mathrm{BC}$ (or cal BP) ages represent the midpoints of bidecadal wood sections, except as noted in the text. The standard deviation in the ages and $\Delta^{14} \mathrm{C}$ (defined in Stuiver and Polach (1977)) values includes lab error multipliers of 1.23 for Belfast and 1.6 for Seattle after $2500 \mathrm{BC}$, and 1.7 for both labs prior to $2500 \mathrm{BC}$.

\begin{tabular}{|c|c|c|c|c|c|c|c|}
\hline \multirow[b]{2}{*}{ Cal $\mathrm{AD} / \mathrm{BC}$} & \multicolumn{3}{|c|}{${ }^{14} \mathrm{C}$} & \multirow[b]{2}{*}{ Cal $\mathrm{AD} / \mathrm{BC}$} & \multicolumn{3}{|c|}{${ }^{14} \mathrm{C}$} \\
\hline & $\Delta^{14} \mathrm{C} \% 0$ & age (BP) & Cal BP & & $\Delta^{14} \mathrm{C} \% 0$ & age (BP) & Cal BP \\
\hline AD 1940 & $-20.7 \pm .6$ & $178 \pm 5$ & BP 10 & AD 1130 & $-14.4 \pm 1.3$ & $914 \pm 10$ & BP 820 \\
\hline AD 1920 & $-11.9 \pm .5$ & $126 \pm 4$ & BP 30 & AD 1110 & $-16.4 \pm 1.1$ & $949 \pm 9$ & BP 840 \\
\hline AD 1900 & $-4.5 \pm .7$ & $85 \pm 6$ & BP 50 & AD 1090 & $-12.2 \pm 1.0$ & $935 \pm 8$ & BP 860 \\
\hline AD 1880 & $-5.6 \pm .5$ & $113 \pm 4$ & BP 70 & AD 1070 & $-7.4 \pm .9$ & $915 \pm 7$ & BP 880 \\
\hline AD 1860 & $-4.1 \pm .6$ & $120 \pm 5$ & BP 90 & AD 1050 & $-7.1 \pm 1.1$ & $932 \pm 9$ & BP 900 \\
\hline AD 1840 & $-1.3 \pm .5$ & $118 \pm 4$ & BP 110 & AD 1030 & $-9.9 \pm 1.2$ & $974 \pm 10$ & BP 920 \\
\hline AD 1825 & $2.5 \pm .6$ & $101 \pm 5$ & BP 125 & AD 1010 & $-16.0 \pm 1.3$ & $1043 \pm 11$ & BP 940 \\
\hline AD 1810 & $-1.4 \pm .5$ & $148 \pm 4$ & BP 140 & $\mathrm{AD} 990$ & $-16.8 \pm 1.2$ & $1069 \pm 9$ & BP 960 \\
\hline AD 1790 & $-7.8 \pm .6$ & $219 \pm 5$ & BP 160 & $\mathrm{AD} 970$ & $-18.9 \pm 1.2$ & $1105 \pm 10$ & BP 980 \\
\hline AD 1770 & $-.1 \pm .5$ & $176 \pm 4$ & BP 180 & $\mathrm{AD} 952$ & $-20.3 \pm 1.5$ & $1135 \pm 12$ & BP 998 \\
\hline AD 1750 & $3.1 \pm .5$ & $169 \pm 4$ & BP 200 & $\mathrm{AD} 940$ & $-19.4 \pm 1.6$ & $1139 \pm 13$ & BP 1010 \\
\hline D 1730 & $9.7 \pm .5$ & $136 \pm 4$ & BP 220 & $\mathrm{AD} 920$ & $-16.8 \pm 1.3$ & $1137 \pm 11$ & P 1030 \\
\hline D 1710 & $15.5 \pm .4$ & $110 \pm 3$ & BP 240 & $\mathrm{AD} 900$ & $-11.4 \pm 1.2$ & $1112 \pm 10$ & BP 1050 \\
\hline AD 1690 & $14.7 \pm .4$ & $136 \pm 3$ & BP 260 & $\mathrm{AD} 880$ & $-18.9 \pm 1.3$ & $1193 \pm 11$ & BP 1070 \\
\hline AD 1670 & \pm .5 & $207 \pm 4$ & BP 280 & $\mathrm{AD} 860$ & $5 \pm 1.3$ & $1210 \pm 10$ & BP 1090 \\
\hline AD 1650 & $2.4 \pm .5$ & $272 \pm 4$ & BP 300 & $\mathrm{AD} 850$ & $-18.2 \pm 1.3$ & $1216 \pm 10$ & BP 1100 \\
\hline AD 1630 & $-2.8 \pm .5$ & $334 \pm 4$ & BP 320 & $\mathrm{AD} 830$ & $-14.3 \pm 1.4$ & $1204 \pm 11$ & BP 1120 \\
\hline AD 1610 & $-5.0 \pm .5$ & $371 \pm 4$ & BP 340 & AD 810 & $-13.6 \pm 1.4$ & $1218 \pm 11$ & P 1140 \\
\hline AD 1590 & $.1 \pm .6$ & $349 \pm 5$ & BP 360 & AD 790 & $2 \pm 1.0$ & $1218 \pm 9$ & BP 1160 \\
\hline D 1570 & $3.5 \pm .6$ & $341 \pm 5$ & BP 380 & AD 770 & $-15.9 \pm 1.2$ & $1276 \pm 10$ & BP 1180 \\
\hline AD 1550 & $8.3 \pm .5$ & $322 \pm 4$ & BP 400 & $\mathrm{AD} 750$ & $9 \pm 1.0$ & $1295 \pm 8$ & BP 1200 \\
\hline AD 1530 & $11.1 \pm .5$ & $319 \pm 4$ & BP 420 & AD 730 & $-10.1 \pm 1.0$ & $1267 \pm 8$ & P 1220 \\
\hline AD 1510 & $8.2 \pm .7$ & $362 \pm 5$ & BP 440 & AD 710 & $-10.6 \pm 1.2$ & $1291 \pm 9$ & P 1240 \\
\hline AD 1490 & \pm 1.4 & $365 \pm 11$ & BP 460 & AD 690 & $-9.2 \pm 1.8$ & $1299 \pm 15$ & $P 1260$ \\
\hline AD 1470 & \pm 1.6 & $405 \pm 13$ & BP 480 & $\mathrm{AD} \quad 670$ & .8 & $1343 \pm 14$ & P 1280 \\
\hline AD 1460 & $8.7 \pm 1.1$ & $406 \pm 9$ & BP 490 & $\mathrm{AD} \quad 650$ & $-18.5 \pm 1.4$ & $1414 \pm 12$ & BP 1300 \\
\hline AD 1450 & $7.6 \pm 1.3$ & $425 \pm 11$ & BP 500 & $\mathrm{AD} \quad 630$ & $-20.4 \pm 1.5$ & $1448 \pm 13$ & BP 1320 \\
\hline AD 1430 & $.4 \pm 1.6$ & $502 \pm 13$ & BP 520 & $\mathrm{AD} \quad 610$ & $-20.6 \pm 1.9$ & $1469 \pm 15$ & BP 1340 \\
\hline AD 1410 & $-1.9 \pm 1.4$ & $540 \pm 12$ & BP 540 & AD 590 & $-23.5 \pm 1.7$ & $1512 \pm 14$ & BP 1360 \\
\hline AD 1390 & $-9.6 \pm 1.3$ & $622 \pm 10$ & BP 560 & AD 570 & $-20.0 \pm 1.8$ & $1503 \pm 14$ & BP 1380 \\
\hline AD 1370 & $-11.2 \pm 1.2$ & $654 \pm 10$ & BP 580 & AD 550 & \pm 1.5 & $1523 \pm 13$ & P 1400 \\
\hline AD 1350 & $-5.2 \pm 1.4$ & $=11$ & BP 600 & AD 530 & \pm 1.4 & $1584 \pm 12$ & BP 1420 \\
\hline AD 1330 & $.8 \pm 1.2$ & $596 \pm 10$ & BP 620 & AD 510 & $-22.3 \pm 1.6$ & $1580 \pm 13$ & BP 1440 \\
\hline AD 1310 & $-.9 \pm 1.2$ & $629 \pm 9$ & BP 640 & AD 490 & $-20.6 \pm 1.6$ & $1586 \pm 13$ & BP 1460 \\
\hline AD 1290 & $-8.7 \pm 1.4$ & $711 \pm 11$ & BP 660 & AD 470 & $-17.0 \pm 1.7$ & $1576 \pm 14$ & BP 1480 \\
\hline AD 1275 & $-15.6 \pm 2.9$ & $782 \pm 24$ & BP 675 & $\mathrm{AD} 450$ & $-15.5 \pm 1.7$ & $1583 \pm 14$ & BP 1500 \\
\hline AD 1260 & $-15.3 \pm 1.2$ & $794 \pm 10$ & BP 690 & AD 430 & $-16.8 \pm 1.6$ & $1613 \pm 13$ & BP 1520 \\
\hline AD 1245 & $-15.4 \pm 2.8$ & $810 \pm 23$ & BP 705 & AD 410 & \pm 1.6 & $1664 \pm 14$ & BP 1540 \\
\hline AD 1230 & $-14.6 \pm 1.1$ & $818 \pm 9$ & BP 720 & AD 390 & $-21.3 \pm 1.4$ & $1689 \pm 11$ & BP 1560 \\
\hline AD 1212 & $-18.3 \pm 1.6$ & $865 \pm 13$ & BP 738 & AD 370 & $-22.1 \pm 1.3$ & $1715 \pm 11$ & BP 1580 \\
\hline AD 1192 & $-16.6 \pm 1.6$ & $871 \pm 13$ & BP 758 & AD 350 & $-18.5 \pm 1.7$ & $1705 \pm 14$ & BP 1600 \\
\hline AD 1170 & $-15.5 \pm 1.0$ & $883 \pm 9$ & BP 780 & AD 330 & $-20.1 \pm 1.7$ & $1737 \pm 14$ & BP 1620 \\
\hline AD 1150 & $-21.3 \pm 1.0$ & $950 \pm 9$ & BP 800 & AD 310 & $-22.7 \pm 1.7$ & $1778 \pm 14$ & BP 1640 \\
\hline
\end{tabular}


TABLE 1. (Continued)

\begin{tabular}{|c|c|c|c|c|c|c|c|c|}
\hline \multirow[b]{2}{*}{ Cal } & \multicolumn{4}{|c|}{${ }^{14} \mathrm{C}$} & \multicolumn{4}{|c|}{${ }^{14} \mathrm{C}$} \\
\hline & $\mathrm{AD} / \mathrm{BC}$ & $\Delta{ }^{14} \mathrm{C} \% 0$ & age (BP) & $\mathrm{Cal} \mathrm{BP}$ & $\mathrm{Cal} \mathrm{AD} / \mathrm{BC}$ & $\Delta^{14} \mathrm{C} \% 0$ & age (BP) & Cal BP \\
\hline$A D$ & 290 & $-17.1 \pm 1.6$ & $1752 \pm 13$ & BP 1660 & $2670 \mathrm{BC}$ & $43.9 \pm 1.6$ & $4143 \pm 12$ & $\overline{\text { BP } 4619}$ \\
\hline $\mathrm{AD}$ & 270 & $-11.4 \pm 1.5$ & $1724 \pm 12$ & BP 1680 & $2690 \mathrm{BC}$ & $46.7 \pm 1.7$ & $4141 \pm 13$ & BP 4639 \\
\hline $\mathrm{AD}$ & 250 & $-15.4 \pm 1.1$ & $1777 \pm 9$ & BP 1700 & 2710 BC & $42.3 \pm 1.6$ & $4194 \pm 12$ & ВР 4659 \\
\hline $\mathrm{AD}$ & 230 & $-18.3 \pm 1.5$ & $1820 \pm 13$ & BP 1720 & $2730 \mathrm{BC}$ & $50.0 \pm 1.6$ & $4155 \pm 12$ & BP 4679 \\
\hline $\mathrm{AD}$ & 210 & $-19.1 \pm 1.5$ & $1846 \pm 13$ & BP 1740 & $2750 \mathrm{BC}$ & $51.0 \pm 2.0$ & $4167 \pm 15$ & BP 4699 \\
\hline $\mathrm{AD}$ & 190 & $-17.2 \pm 1.7$ & $1850 \pm 14$ & BP 1760 & 2770 вC & $51.0 \pm 2.2$ & $4186 \pm 17$ & BP 4719 \\
\hline $\mathrm{AD}$ & 170 & $-14.8 \pm 1.8$ & $1849 \pm 15$ & BP 1780 & 2790 BC & $50.4 \pm 1.6$ & $4210 \pm 13$ & BP 4739 \\
\hline $\mathrm{AD}$ & 150 & $-11.6 \pm 1.7$ & $1843 \pm 14$ & BP 1800 & $2810 \mathrm{BC}$ & $58.9 \pm 1.8$ & $4165 \pm 14$ & BP 4759 \\
\hline $\mathrm{AD}$ & 130 & $-13.6 \pm 1.2$ & $1879 \pm 10$ & BP 1820 & $2830 \mathrm{BC}$ & $68.9 \pm 1.5$ & $4109 \pm 12$ & BP 4779 \\
\hline $\mathrm{AD}$ & 110 & $-16.2 \pm 1.8$ & $1919 \pm 15$ & BP 1840 & $2850 \mathrm{BC}$ & $68.5 \pm 1.8$ & $4131 \pm 14$ & BP 4799 \\
\hline$A D$ & 90 & $-12.0 \pm 1.4$ & $1904 \pm 12$ & BP 1860 & $2870 \mathrm{BC}$ & $63.5 \pm 1.8$ & $4188 \pm 13$ & BP 4819 \\
\hline $\mathrm{AD}$ & 70 & $-15.7 \pm 1.3$ & $1954 \pm 11$ & BP 1880 & 2890 BC & $54.2 \pm 2.0$ & $4278 \pm 15$ & BP 4839 \\
\hline $\mathrm{AD}$ & 50 & $-16.9 \pm 1.1$ & $1984 \pm 9$ & BP 1900 & 2910 BC & $52.7 \pm 1.9$ & $4309 \pm 15$ & BP 4859 \\
\hline $\mathrm{AD}$ & 30 & $-13.3 \pm 1.4$ & $1974 \pm 11$ & BP 1920 & 2930 BC & $43.6 \pm 2.1$ & $4398 \pm 16$ & BP 4879 \\
\hline $\mathrm{AD}$ & 10 & $-14.6 \pm 1.1$ & $2003 \pm 9$ & BP 1940 & 2950 BC & $45.8 \pm 1.7$ & $4401 \pm 13$ & BP 4899 \\
\hline & $\mathrm{BC}$ & $-15.8 \pm 1.1$ & $2032 \pm 9$ & BP 1959 & 2970 BC & $48.2 \pm 2.3$ & $4402 \pm 17$ & BP 4919 \\
\hline & $\mathrm{BC}$ & $-12.9 \pm 1.0$ & $2027 \pm 8$ & BP 1979 & 2990 BC & $53.6 \pm 1.8$ & $4380 \pm 14$ & BP 4939 \\
\hline & $\mathrm{BC}$ & $-15.9 \pm 1.0$ & $2071 \pm 8$ & BP 1999 & 3010 BC & $56.8 \pm 2.1$ & $4375 \pm 16$ & BP 4959 \\
\hline & $\mathrm{BC}$ & $-16.2 \pm 1.2$ & $2093 \pm 10$ & BP 2019 & 3030 вС & $55.8 \pm 2.0$ & $4402 \pm 15$ & BP 4979 \\
\hline & $\mathrm{BC}$ & $-13.4 \pm 1.2$ & $2090 \pm 10$ & BP 2039 & 3050 BC & $51.5 \pm 1.6$ & $4454 \pm 12$ & BP 4999 \\
\hline 110 & $0 \mathrm{BC}$ & $-13.1 \pm 1.2$ & $2107 \pm 9$ & BP 2059 & 3070 вС & $58.4 \pm 1.6$ & $4421 \pm 12$ & BP 5019 \\
\hline 130 & $0 \mathrm{BC}$ & $-12.8 \pm 1.3$ & $2124 \pm 10$ & BP 2079 & 3090 BC & $57.5 \pm 2.2$ & $4447 \pm 17$ & BP 5039 \\
\hline 150 & $0 \mathrm{BC}$ & $-9.0 \pm 1.4$ & $2112 \pm 11$ & BP 2099 & 3110 вС & $52.0 \pm 2.1$ & $4509 \pm 16$ & BP 5059 \\
\hline 17 & $0 \mathrm{BC}$ & $-9.5 \pm 1.3$ & $2136 \pm 10$ & BP 2119 & 3130 BC & $52.5 \pm 2.1$ & $4525 \pm 16$ & BP 5079 \\
\hline 19 & $0 \mathrm{BC}$ & $-10.2 \pm 1.3$ & $2161 \pm 11$ & BP 2139 & $3150 \mathrm{BC}$ & $53.1 \pm 2.1$ & $4540 \pm 16$ & BP 5099 \\
\hline 210 & $0 \mathrm{BC}$ & $-16.0 \pm 1.2$ & $2228 \pm 10$ & BP 2159 & 3170 BC & $61.1 \pm 2.0$ & $4498 \pm 15$ & BP 5119 \\
\hline 230 & $0 \mathrm{BC}$ & $-13.3 \pm 1.3$ & $2225 \pm 10$ & BP 2179 & 3190 вС & $60.2 \pm 1.7$ & $4524 \pm 13$ & BP 5139 \\
\hline 25 & $0 \mathrm{BC}$ & $-11.6 \pm 1.5$ & $2230 \pm 12$ & BP 2199 & 3210 BC & $61.9 \pm 1.8$ & $4530 \pm 14$ & BP 5159 \\
\hline 27 & $0 \mathrm{BC}$ & $-12.6 \pm 1.5$ & $2258 \pm 12$ & BP 2219 & $3230 \mathrm{BC}$ & $66.8 \pm 2.0$ & $4513 \pm 15$ & BP 5179 \\
\hline 29 & $0 \mathrm{BC}$ & $-6.4 \pm 1.5$ & $2227 \pm 12$ & BP 2239 & $3250 \mathrm{BC}$ & $75.9 \pm 2.1$ & $4465 \pm 15$ & BP 5199 \\
\hline 310 & $0 \mathrm{BC}$ & $-2.7 \pm 1.5$ & $2217 \pm 12$ & BP 2259 & $3270 \mathrm{BC}$ & $74.0 \pm 2.3$ & $4498 \pm 17$ & BP 5219 \\
\hline 33 & $0 \mathrm{BC}$ & $2.7 \pm 1.5$ & $2193 \pm 12$ & BP 2279 & $3290 \mathrm{BC}$ & $78.2 \pm 2.1$ & $4486 \pm 16$ & BP 5239 \\
\hline 35 & $0 \mathrm{BC}$ & $2.6 \pm 1.3$ & $2213 \pm 11$ & BP 2299 & $3310 \mathrm{BC}$ & $76.1 \pm 1.9$ & $4521 \pm 14$ & BP 5259 \\
\hline 37 & $0 \mathrm{BC}$ & $-1.4 \pm 1.2$ & $2264 \pm 10$ & BP 2319 & 3330 BC & $78.7 \pm 1.7$ & $4521 \pm 12$ & BP 5279 \\
\hline 39 & $0 \mathrm{BC}$ & $-5.0 \pm 1.4$ & $2313 \pm 12$ & BP 2339 & $3350 \mathrm{BC}$ & $73.9 \pm 1.8$ & $4577 \pm 14$ & BP 5299 \\
\hline 41 & $0 \mathrm{BC}$ & $-15.3 \pm 1.3$ & $2416 \pm 11$ & BP 2359 & 3370 вС & $68.0 \pm 2.4$ & $4640 \pm 18$ & BP 5319 \\
\hline 43 & $0 \mathrm{BC}$ & $-16.2 \pm 1.3$ & $2443 \pm 11$ & BP 2379 & 3390 вC & $58.7 \pm 2.0$ & $4730 \pm 15$ & BP 5339 \\
\hline 45 & $0 \mathrm{BC}$ & $-12.2 \pm 1.6$ & $2430 \pm 13$ & BP 2399 & 3410 BC & $63.9 \pm 2.4$ & $4710 \pm 18$ & BP 5359 \\
\hline 47 & $0 \mathrm{BC}$ & $-9.1 \pm 1.3$ & $2424 \pm 10$ & BP 2419 & 3430 BC & $69.9 \pm 1.9$ & $4685 \pm 15$ & BP 5379 \\
\hline 49 & $0 \mathrm{BC}$ & $-8.3 \pm 1.4$ & $2437 \pm 11$ & BP 2439 & $3450 \mathrm{BC}$ & $71.6 \pm 2.5$ & $4691 \pm 19$ & BP 5399 \\
\hline 251 & $0 \mathrm{BC}$ & $34.9 \pm 1.5$ & $4058 \pm 12$ & BP 4459 & $3470 \mathrm{BC}$ & $79.7 \pm 1.9$ & $4650 \pm 14$ & BP 5419 \\
\hline 253 & $0 \mathrm{BC}$ & $42.9 \pm 1.5$ & $4015 \pm 11$ & BP 4479 & $3490 \mathrm{BC}$ & $83.1 \pm 1.9$ & $4644 \pm 14$ & BP 5439 \\
\hline 255 & $0 \mathrm{BC}$ & $46.5 \pm 1.6$ & $4007 \pm 12$ & ВР 4499 & 3510 вС & $74.6 \pm 1.9$ & $4726 \pm 14$ & BP 5459 \\
\hline 257 & 0 BC & $43.7 \pm 1.5$ & $4048 \pm 12$ & BP 4519 & $3530 \mathrm{BC}$ & $73.6 \pm 1.9$ & $4753 \pm 14$ & BP 5479 \\
\hline 259 & $0 \mathrm{BC}$ & $40.9 \pm 1.5$ & $4088 \pm 11$ & BP 4539 & $3550 \mathrm{BC}$ & $69.9 \pm 1.9$ & $4801 \pm 14$ & BP 5499 \\
\hline 261 & $0 \mathrm{BC}$ & $43.7 \pm 2.0$ & $4087 \pm 15$ & BP 4559 & $3570 \mathrm{BC}$ & $75.9 \pm 1.9$ & $4776 \pm 14$ & BP 5519 \\
\hline 263 & $0 \mathrm{BC}$ & $39.7 \pm 1.4$ & $4137 \pm 11$ & BP 4579 & $3590 \mathrm{BC}$ & $81.6 \pm 1.7$ & $4752 \pm 13$ & BP 5539 \\
\hline 265 & $0 \mathrm{BC}$ & $44.5 \pm 2.1$ & $4119 \pm 16$ & ВP 4599 & $3610 \mathrm{BC}$ & $87.7 \pm 1.6$ & $4726 \pm 12$ & BP 5559 \\
\hline
\end{tabular}


TABLE 1. (Continued)

\begin{tabular}{|c|c|c|c|c|c|c|c|}
\hline \multicolumn{4}{|c|}{${ }^{14} \mathrm{C}$} & \multicolumn{4}{|c|}{${ }^{14} \mathrm{C}$} \\
\hline $\mathrm{Cal} \mathrm{AD} / \mathrm{BC}$ & $\Delta^{14} \mathrm{C} \% 0$ & age (BP) & Cal BP & $\mathrm{Cal} \mathrm{AD} / \mathrm{BC}$ & $\Delta^{14} \mathrm{C} \% 0$ & age (BP) & $\mathrm{Cal} \mathrm{BP}$ \\
\hline $3630 \mathrm{BC}$ & $81.4 \pm 2.1$ & $4793 \pm 16$ & BP 5579 & $4590 \mathrm{BC}$ & $77.1 \pm 2.1$ & $5757 \pm 16$ & BP 6539 \\
\hline $3650 \mathrm{BC}$ & $73.6 \pm 1.9$ & $4871 \pm 14$ & BP 5599 & 4610 BC & $78.2 \pm 2.4$ & $5769 \pm 18$ & BP 6559 \\
\hline 3670 вС & $71.5 \pm 1.7$ & $4905 \pm 13$ & BP 5619 & $4630 \mathrm{BC}$ & $76.7 \pm 1.9$ & $5799 \pm 14$ & BP 6579 \\
\hline $3690 \mathrm{BC}$ & $75.1 \pm 1.8$ & $4898 \pm 14$ & BP 5639 & $4650 \mathrm{BC}$ & $83.2 \pm 1.7$ & $5770 \pm 13$ & BP 6599 \\
\hline $3710 \mathrm{BC}$ & $70.7 \pm 1.8$ & $4950 \pm 14$ & BP 5659 & $4670 \mathrm{BC}$ & $86.2 \pm 2.5$ & $5768 \pm 18$ & BP 6619 \\
\hline 3730 BC & $71.4 \pm 2.1$ & $4965 \pm 16$ & BP 5679 & $4690 \mathrm{BC}$ & $83.7 \pm 1.8$ & $5806 \pm 13$ & BP 6639 \\
\hline 3750 вС & $75.0 \pm 1.8$ & $4957 \pm 13$ & BP 5699 & $4710 \mathrm{BC}$ & $84.2 \pm 2.1$ & $5821 \pm 15$ & BP 6659 \\
\hline $3770 \mathrm{BC}$ & $73.8 \pm 1.8$ & $4985 \pm 14$ & BP 5719 & $4730 \mathrm{BC}$ & $80.0 \pm 2.5$ & $5872 \pm 18$ & BP 6679 \\
\hline $3790 \mathrm{BC}$ & $73.0 \pm 1.7$ & $5011 \pm 13$ & BP 5739 & $4750 \mathrm{BC}$ & $86.6 \pm 2.5$ & $5842 \pm 18$ & BP 6699 \\
\hline 3810 вC & $67.4 \pm 2.0$ & $5073 \pm 15$ & BP 5759 & $4770 \mathrm{BC}$ & $84.7 \pm 2.5$ & $5876 \pm 18$ & BP 6719 \\
\hline $3830 \mathrm{BC}$ & $67.8 \pm 2.2$ & $5089 \pm 16$ & BP 5779 & 4790 вС & $82.5 \pm 2.5$ & $5912 \pm 19$ & BP 6739 \\
\hline $3850 \mathrm{BC}$ & $70.9 \pm 1.6$ & $5085 \pm 12$ & BP 5799 & $4810 \mathrm{BC}$ & $81.3 \pm 2.5$ & $5940 \pm 19$ & BP 6759 \\
\hline $3870 \mathrm{BC}$ & $75.3 \pm 1.4$ & $5071 \pm 10$ & BP 5819 & $4830 \mathrm{BC}$ & $82.7 \pm 2.2$ & $5949 \pm 17$ & BP 6779 \\
\hline 3890 BC & $83.9 \pm 1.7$ & $5027 \pm 13$ & BP 5839 & $4850 \mathrm{BC}$ & $80.0 \pm 2.2$ & $5989 \pm 16$ & BP 6799 \\
\hline 3910 BC & $82.3 \pm 1.6$ & $5058 \pm 12$ & BP 5859 & $4870 \mathrm{BC}$ & $80.1 \pm 2.5$ & $6007 \pm 19$ & ВР 6819 \\
\hline 3930 BC & $84.6 \pm 1.9$ & $5060 \pm 14$ & BP 5879 & 4890 вС & $89.3 \pm 2.3$ & $5959 \pm 17$ & BP 6839 \\
\hline $3950 \mathrm{BC}$ & $80.4 \pm 1.7$ & $5111 \pm 13$ & BP 5899 & $4910 \mathrm{BC}$ & $85.3 \pm 1.8$ & $6008 \pm 13$ & BP 6859 \\
\hline 3970 вC & $75.8 \pm 1.3$ & $5165 \pm 10$ & ВР 5919 & 4930 BC & $85.4 \pm 1.7$ & $6026 \pm 13$ & BP 6879 \\
\hline 3990 ВС & $71.4 \pm 1.7$ & $5217 \pm 13$ & BP 5939 & $4950 \mathrm{BC}$ & $82.3 \pm 1.5$ & $6069 \pm 12$ & PP 6899 \\
\hline $4010 \mathrm{BC}$ & $68.9 \pm 1.9$ & $5255 \pm 15$ & BP 5959 & $4970 \mathrm{BC}$ & $82.7 \pm 1.7$ & $6085 \pm 13$ & ВР 6919 \\
\hline $4030 \mathrm{BC}$ & $76.3 \pm 1.7$ & $5219 \pm 13$ & ВР 5979 & 4990 ВC & $84.6 \pm 1.9$ & $6091 \pm 14$ & ВР 6939 \\
\hline $4050 \mathrm{BC}$ & $70.7 \pm 2.0$ & $5281 \pm 15$ & BP 5999 & $5010 \mathrm{BC}$ & $84.6 \pm 2.4$ & $6110 \pm 18$ & BP 6959 \\
\hline $4070 \mathrm{BC}$ & $78.3 \pm 1.9$ & $5244 \pm 15$ & BP 6019 & $5030 \mathrm{BC}$ & $87.8 \pm 2.5$ & $6106 \pm 19$ & ВР 6979 \\
\hline 4090 BC & $72.7 \pm 1.8$ & $5305 \pm 14$ & BP 6039 & $5050 \mathrm{BC}$ & $88.4 \pm 2.5$ & $6121 \pm 18$ & ВР 6999 \\
\hline 4110 BC & $72.6 \pm 2.1$ & $5324 \pm 16$ & BP 6059 & $5070 \mathrm{BC}$ & $84.6 \pm 2.2$ & $6168 \pm 16$ & BP 7019 \\
\hline $4130 \mathrm{BC}$ & $81.3 \pm 2.1$ & $5279 \pm 16$ & ВР 6079 & 5090 вС & $82.4 \pm 1.8$ & $6204 \pm 13$ & BP 7039 \\
\hline $4150 \mathrm{BC}$ & $78.6 \pm 4.8$ & $5319 \pm 36$ & BP 6099 & 5110 вС & $85.7 \pm 2.0$ & $6199 \pm 15$ & BP 7059 \\
\hline $4170 \mathrm{BC}$ & $76.3 \pm 2.3$ & $5355 \pm 17$ & BP 6119 & $5130 \mathrm{BC}$ & $91.9 \pm 2.0$ & $6172 \pm 14$ & BP 7079 \\
\hline $4190 \mathrm{BC}$ & $82.1 \pm 2.1$ & $5332 \pm 16$ & BP 6139 & $5150 \mathrm{BC}$ & $85.0 \pm 2.5$ & $6243 \pm 19$ & BP 7099 \\
\hline $4210 \mathrm{BC}$ & $92.9 \pm 2.4$ & $5271 \pm 18$ & BP 6159 & $5170 \mathrm{BC}$ & $93.8 \pm 2.0$ & $6197 \pm 15$ & BP 7119 \\
\hline $4230 \mathrm{BC}$ & $82.2 \pm 1.8$ & $5370 \pm 14$ & BP 6179 & $5190 \mathrm{BC}$ & $103.0 \pm 2.1$ & $6150 \pm 16$ & BP 7139 \\
\hline $4250 \mathrm{BC}$ & $81.8 \pm 2.1$ & $5392 \pm 16$ & BP 6199 & $5210 \mathrm{BC}$ & $98.5 \pm 2.5$ & $6202 \pm 18$ & BP 7159 \\
\hline 4270 вC & $76.8 \pm 2.2$ & $5449 \pm 16$ & BP 6219 & $5230 \mathrm{BC}$ & $92.2 \pm 2.5$ & $6268 \pm 18$ & BP 7179 \\
\hline $4290 \mathrm{BC}$ & $83.3 \pm 2.1$ & $5420 \pm 16$ & BР 6239 & $5250 \mathrm{BC}$ & $94.1 \pm 1.9$ & $6273 \pm 14$ & BP 7199 \\
\hline $4310 \mathrm{BC}$ & $89.6 \pm 2.3$ & $5393 \pm 17$ & BP 6259 & $5270 \mathrm{BC}$ & $88.7 \pm 2.0$ & $6332 \pm 15$ & BP 7219 \\
\hline $4330 \mathrm{BC}$ & $84.1 \pm 2.1$ & $5453 \pm 15$ & BР 6279 & 5290 вC & $84.7 \pm 2.1$ & $6381 \pm 16$ & BP 7239 \\
\hline $4350 \mathrm{BC}$ & $77.8 \pm 2.0$ & $5519 \pm 15$ & BP 6299 & $5310 \mathrm{BC}$ & $87.6 \pm 2.2$ & $6379 \pm 16$ & BP 7259 \\
\hline $4370 \mathrm{BC}$ & $72.4 \pm 1.9$ & $5579 \pm 15$ & BP 6319 & $5330 \mathrm{BC}$ & $86.2 \pm 2.1$ & $6409 \pm 16$ & BP 7279 \\
\hline 4390 BC & $76.4 \pm 2.4$ & $5568 \pm 18$ & BP 6339 & $5350 \mathrm{BC}$ & $82.4 \pm 2.0$ & $6457 \pm 15$ & BP 7299 \\
\hline 4410 BC & $74.6 \pm 2.4$ & $5601 \pm 18$ & BP 6359 & $5370 \mathrm{BC}$ & $90.5 \pm 2.5$ & $6416 \pm 18$ & BP 7319 \\
\hline $4430 \mathrm{BC}$ & $83.9 \pm 2.4$ & $5552 \pm 18$ & BP 6379 & 5390 вС & $86.9 \pm 2.5$ & $6462 \pm 19$ & BP 7339 \\
\hline $4450 \mathrm{BC}$ & $82.8 \pm 2.4$ & $5579 \pm 18$ & ВР 6399 & $5410 \mathrm{BC}$ & $95.4 \pm 2.2$ & $6419 \pm 16$ & BP 7359 \\
\hline $4470 \mathrm{BC}$ & $73.1 \pm 2.0$ & $5671 \pm 15$ & BP 6419 & 5430 вС & $92.8 \pm 2.2$ & $6457 \pm 16$ & BP 7379 \\
\hline 4490 вС & $76.4 \pm 2.4$ & $5666 \pm 18$ & BP 6439 & $5450 \mathrm{BC}$ & $78.3 \pm 2.2$ & $6585 \pm 16$ & ВP 7399 \\
\hline $4510 \mathrm{BC}$ & $76.7 \pm 2.4$ & $5683 \pm 18$ & BP 6459 & $5470 \mathrm{BC}$ & $82.8 \pm 2.2$ & $6570 \pm 16$ & BP 7419 \\
\hline $4530 \mathrm{BC}$ & $77.5 \pm 2.5$ & $5696 \pm 18$ & BP 6479 & 5490 вС & $81.4 \pm 2.5$ & $6600 \pm 18$ & BP 7439 \\
\hline $4550 \mathrm{BC}$ & $73.9 \pm 2.5$ & $5742 \pm 18$ & BP 6499 & $5500 \mathrm{BC}$ & $82.1 \pm 2.6$ & $6605 \pm 19$ & BP 7449 \\
\hline $4570 \mathrm{BC}$ & $75.7 \pm 1.9$ & $5748 \pm 14$ & ВР 6519 & $5510 \mathrm{BC}$ & $82.8 \pm 2.5$ & $6609 \pm 18$ & BP 7459 \\
\hline
\end{tabular}


TABLE 1. (Continued)

\begin{tabular}{llll|llll}
\hline Cal AD/BC & $\Delta^{14} \mathrm{C} \% 0$ & age (BP) & Cal BP & Cal AD/BC & $\Delta^{14} \mathrm{C} \% 0$ & age (BP) & Cal BP \\
\hline $5520 \mathrm{BC}$ & $84.2 \pm 2.6$ & $6608 \pm 19$ & BP 7469 & $5740 \mathrm{BC}$ & $69.8 \pm 1.6$ & $6930 \pm 12$ & BP 7689 \\
$5530 \mathrm{BC}$ & $76.0 \pm 2.4$ & $6679 \pm 18$ & BP 7479 & $5760 \mathrm{BC}$ & $70.9 \pm 1.6$ & $6941 \pm 12$ & BP 7709 \\
$5540 \mathrm{BC}$ & $76.9 \pm 2.6$ & $6682 \pm 19$ & BP 7489 & $5780 \mathrm{BC}$ & $70.2 \pm 1.7$ & $6966 \pm 12$ & BP 7729 \\
$5550 \mathrm{BC}$ & $85.8 \pm 2.2$ & $6626 \pm 16$ & BP 7499 & $5800 \mathrm{BC}$ & $72.1 \pm 1.6$ & $6971 \pm 12$ & BP 7749 \\
$5560 \mathrm{BC}$ & $89.4 \pm 2.2$ & $6609 \pm 17$ & BP 7509 & $5820 \mathrm{BC}$ & $72.0 \pm 1.6$ & $6991 \pm 12$ & BP 7769 \\
$5570 \mathrm{BC}$ & $85.7 \pm 1.8$ & $6646 \pm 13$ & BP 7519 & $5840 \mathrm{BC}$ & $74.2 \pm 1.7$ & $6994 \pm 13$ & BP 7789 \\
$5580 \mathrm{BC}$ & $81.0 \pm 1.8$ & $6691 \pm 13$ & BP 7529 & $5860 \mathrm{BC}$ & $72.8 \pm 2.5$ & $7024 \pm 19$ & BP 7809 \\
$5590 \mathrm{BC}$ & $78.1 \pm 2.0$ & $6722 \pm 15$ & BP 7539 & $5880 \mathrm{BC}$ & $72.1 \pm 2.5$ & $7049 \pm 19$ & BP 7829 \\
$5600 \mathrm{BC}$ & $73.5 \pm 1.9$ & $6766 \pm 14$ & BP 7549 & $5900 \mathrm{BC}$ & $70.0 \pm 2.3$ & $7084 \pm 17$ & BP 7849 \\
$5620 \mathrm{BC}$ & $74.4 \pm 1.6$ & $6778 \pm 12$ & BP 7569 & $5920 \mathrm{BC}$ & $83.3 \pm 2.1$ & $7004 \pm 15$ & BP 7869 \\
$5640 \mathrm{BC}$ & $72.7 \pm 1.7$ & $6811 \pm 13$ & BP 7589 & $5940 \mathrm{BC}$ & $79.3 \pm 2.7$ & $7053 \pm 20$ & BP 7889 \\
$5660 \mathrm{BC}$ & $75.6 \pm 1.6$ & $6809 \pm 12$ & BP 7609 & $5960 \mathrm{BC}$ & $74.1 \pm 2.5$ & $7111 \pm 19$ & BP 7909 \\
$5680 \mathrm{BC}$ & $73.8 \pm 1.8$ & $6842 \pm 14$ & BP 7629 & $5980 \mathrm{BC}$ & $69.5 \pm 2.3$ & $7165 \pm 17$ & BP 7929 \\
$5700 \mathrm{BC}$ & $71.7 \pm 1.7$ & $6877 \pm 13$ & BP 7649 & $6000 \mathrm{BC}$ & $69.3 \pm 2.3$ & $7186 \pm 17$ & BP 7949 \\
$5720 \mathrm{BC}$ & $71.0 \pm 2.0$ & $6901 \pm 15$ & BP 7669 & & & &
\end{tabular}

